\title{
Nanomaterial-Based Antifungal Therapies to Combat Fungal Diseases Aspergillosis, Coccidioidomycosis, Mucormycosis, and Candidiasis
}

\author{
Angel León-Buitimea ${ }^{1,2,+}{ }^{\mathbb{D}}$, Javier A. Garza-Cervantes ${ }^{1,2,+}$, Diana Y. Gallegos-Alvarado ${ }^{1}$, \\ Macario Osorio-Concepción 1,2 (D) and José Ruben Morones-Ramírez 1,2,*(D) \\ 1 Facultad de Ciencias Químicas, Universidad Autónoma de Nuevo León (UANL), \\ San Nicolás de los Garza C.P. 66455, Mexico; angel.deb@uanl.edu.mx (A.L.-B.); \\ javier.garzacn@uanl.edu.mx (J.A.G.-C.); yamilet.gallegosalvrd@uanl.edu.mx (D.Y.G.-A.); \\ m.osoriocn@gmail.com (M.O.-C.) \\ 2 Centro de Investigación en Biotecnología y Nanotecnología, Facultad de Ciencias Químicas, \\ Parque de Investigación e Innovación Tecnológica, Universidad Autónoma de Nuevo León, \\ Apodaca C.P. 66628, Mexico \\ * Correspondence: jose.moronesrmr@uanl.edu.mx \\ + These authors have contributed equally to this work.
}

Citation: León-Buitimea, A.; Garza-Cervantes, J.A.; Gallegos-Alvarado, D.Y.; Osorio-Concepción, M.;

Morones-Ramírez, J.R.

Nanomaterial-Based Antifungal Therapies to Combat Fungal Diseases Aspergillosis, Coccidioidomycosis, Mucormycosis, and Candidiasis. Pathogens 2021, 10, 1303. https:// doi.org/10.3390/pathogens10101303

Academic Editor: Ying-Lien Chen

Received: 26 August 2021

Accepted: 3 October 2021

Published: 12 October 2021

Publisher's Note: MDPI stays neutral with regard to jurisdictional claims in published maps and institutional affiliations.

Copyright: (c) 2021 by the authors. Licensee MDPI, Basel, Switzerland. This article is an open access article distributed under the terms and conditions of the Creative Commons Attribution (CC BY) license (https:/ / creativecommons.org/licenses/by/ $4.0 /)$.

\begin{abstract}
Over the last years, invasive infections caused by filamentous fungi have constituted a serious threat to public health worldwide. Aspergillus, Coccidioides, Mucorales (the most common filamentous fungi), and Candida auris (non-filamentous fungus) can cause infections in humans. They are able to cause critical life-threatening illnesses in immunosuppressed individuals, patients with HIV / AIDS, uncontrolled diabetes, hematological diseases, transplantation, and chemotherapy. In this review, we describe the available nanoformulations (both metallic and polymers-based nanoparticles) developed to increase efficacy and reduce the number of adverse effects after the administration of conventional antifungals. To treat aspergillosis and infections caused by Candida, multiple strategies have been used to develop new therapeutic alternatives, such as incorporating coating materials, complexes synthesized by green chemistry, or coupled with polymers. However, the therapeutic options for coccidioidomycosis and mucormycosis are limited; most of them are in the early stages of development. Therefore, more research needs to be performed to develop new therapeutic alternatives that contribute to the progress of this field.
\end{abstract}

Keywords: nanomaterials; antifungal therapies; aspergillosis; coccidioidomycosis; mucormycosis; candidiasis

\section{Introduction}

Fungi constitute a diverse group of eukaryotic organisms with distinct morphological traits colonizing different ecological niches [1]. It has been estimated the presence of 3 to 5 million fungi in the environment, of which about 300 species present the ability to establish and develop infections in human beings [2-4]. Most of these fungal group members are considered opportunistic pathogens because they commonly infect patients with a weak immune system $[4,5]$. In the meantime, only a reduced number of species represent a serious threat to healthy patients [5]. The human pathogenic fungi cause various infection types, such as skin, mucosal, and invasive infections [6]. The success of pathogenic fungi to cause the disease in humans is because they tolerate high temperatures $\left(37^{\circ} \mathrm{C}\right)$, fast growth, invade tissues, use the host nutrients for their benefit, and evade the host immune system [3,4]. Some of the fungal genera responsible for the most frequent lethal infections are Aspergillus, Cryptococcus, Candida, Coccidioides, Mucor, and Rhizopus [5,7].

Despite the availability of traditional and modern antifungal drugs, the prevalence of mycotic infections is still increasing [8,9]. This scenario may be related to fungi's ability to 
develop multi-resistance mechanisms to the existing antimycotic therapies [10]. Furthermore, the current antifungals present some drawbacks in the efficacy, efficiency, selectivity, toxicity, resistance mechanisms, and activity spectrum [11]. Contrary to other infections (bacterial or viral), those caused by fungi have been poorly explored despite the death rates each year (1.5 million) and the severe problem that is presented to the health sector $[12,13]$. In this context, the generation of drug delivery systems based on nanomaterials or nanoparticles (NPs) represents a potential alternative to developing newer pharmaceutical formulations to successfully combat fungal infections and overcome the fungal multi-resistance to existent drugs [14]. Nanoparticles can be synthesized from lipids, polymers, and metals [15-18]. Different research groups have determined that nanoparticles present fewer side effects, greater specificity to the infection site, do not generate drug resistance, improve antimycotic stability and solubility, and increase efficiency [15,19-23]. Due to these characteristics, the different nanoparticle types are considered promising biopharmaceutical systems due to their improved antifungal properties, unlike traditional drugs for treating various fungal pathogens [21]. Thus, this review will be divided into three main sections: an overview of the fungal disease, current treatment, and nanotechnology as the main tool for improving antifungal therapy.

\section{Overview of the Fungal Disease}

Over the last years, the number of invasive filamentous fungal infections has increased considerably. Immunosuppressed individuals with HIV/AIDS, uncontrolled diabetes, hematological diseases, transplantation, and chemotherapy, are more frequently susceptible to fungal infections. Aspergillus, Coccidioides, Mucorales (the most common filamentous fungi), and Candida auris (non-filamentous fungus) can cause infections in humans. They are well characterized and constitute a serious threat to public health worldwide [24]. Nanomaterials (both metallic and polymeric nanoparticles) and their applications as novel strategies for treating the most prevalent invasive filamentous fungal infections are described in this review article. In Table 1, we summarized the geographical distribution and epidemiological data of the most common filamentous and non-filamentous fungi that cause infections in humans.

Table 1. Geographical distribution and epidemiological data of the most common filamentous and non-filamentous fungi.

\begin{tabular}{|c|c|c|c|c|}
\hline Filamentous Fungi & Disease & $\begin{array}{l}\text { Geographical Distribution } \\
\text { (Incidence) }\end{array}$ & Epidemiological Data & References \\
\hline Aspergillus fumigatus & Aspergillosis & Worldwide distribution & $\begin{array}{l}\text { Immunocompromised individuals with } \\
\text { altered or weakened immune responses are } \\
\text { able to develop aspergillosis. }\end{array}$ & {$[25,26]$} \\
\hline $\begin{array}{c}\text { Coccidioides immitis } \\
\text { and Coccidioides } \\
\text { posadasii }\end{array}$ & Coccidioidomycosis & $\begin{array}{l}\text { Central Valley of California, } \\
\text { desert areas of Arizona, Texas, } \\
\text { Utah; Mexico; Central } \\
\text { (Guatemala and Honduras), } \\
\text { and South America (Colombia, } \\
\text { Venezuela, Argentina, } \\
\text { Paraguay, and Brazil). }\end{array}$ & $\begin{array}{l}\text { Elderly persons, pregnant women, and } \\
\text { members of certain ethnic groups are at } \\
\text { risk for severe or disseminated } \\
\text { coccidioidomycosis. Further, persons with } \\
\text { immunodeficiency diseases, diabetes, } \\
\text { transplant recipients, and prisoners are } \\
\text { particularly vulnerable. }\end{array}$ & {$[27,28]$} \\
\hline Rhizopus, Mucor & Mucormycosis & $\begin{array}{c}\text { Europe }(34 \%) \text {, Asia }(31 \%), \\
\text { North/South America }(28 \%), \\
\text { Africa (3\%), and } \\
\text { Australia/New Zealand (3\%) }\end{array}$ & $\begin{array}{l}\text { Patients with uncontrolled diabetes } \\
\text { mellitus, cancer, solid organ or bone } \\
\text { marrow transplantation, hematological } \\
\text { malignancy, corticosteroids treatment, and } \\
\text { trauma and burns are especially vulnerable } \\
\text { to Mucorales infection. }\end{array}$ & {$[7,29]$} \\
\hline $\begin{array}{l}\text { Candida auris } \\
\text { (non-filamentous } \\
\text { fungus) }\end{array}$ & Candidiasis & Worldwide distribution & $\begin{array}{c}\text { Elderly age, diabetes mellitus, recent } \\
\text { surgery, the presence of an indwelling } \\
\text { medical device, an immunosuppressed } \\
\text { state, the use of hemodialysis, a } \\
\text { neutropenic state, chronic renal disease, or } \\
\text { the use of broad-spectrum antibiotic } \\
\text { and/or antifungal drugs are related to } \\
\text { C. auris infections. }\end{array}$ & {$[30,31]$} \\
\hline
\end{tabular}




\subsection{Aspergillosis}

Some molds can produce mycotoxins. Both humans and food can be contaminated with mycotoxins. Mycotoxins have various acute and chronic effects on humans, including allergies, hepatotoxicity, and cancer. Aspergillus is a group in the fungi kingdom belonging to the Ascomycota phylum, Eurotiomycetes class, Eurotiales order, Trichocomaceae family, and Aspergillus genus, and species: niger, fumigatus, flavus, ochraceus [32]. Aspergillus flavus (A. flavus) and Aspergillus fumigatus (A. fumigatus) are two ubiquitous molds capable of producing and releasing mycotoxins. Mold growth is prevalent in hospital environments, causing patient complications and economic losses [33]. A. fumigatus is a saprotrophic fungus, which spreads by asexual sporulation, with vegetative mycelial life in organic material in decay [34]. It can cause lung infections due to the inhalation of airborne conidia present in indoor and outdoor environments. Severe asthma with fungal sensitization, chronic pulmonary aspergillosis, and invasive pulmonary aspergillosis are also related [35-37]. Aspergillus species are the most common cause of corneal disease. Similarly, fungal keratitis, the third clinical presentation of fungal infections, is associated with saprophyte filamentous fungi, such as Aspergillus spp. [38]. Because of this, Aspergillus species are important life-threatening causes of illness, most notably in immunocompromised hosts [39].

\subsection{Coccidioidomycosis}

Coccidioidomycosis, also known as valley fever, is a systemic fungal infection caused by Coccidioides immitis or Coccidioides posadasii. Coccidioides genus (immitis and posadasii species) are fungi within Ascomycete phylum, Eurotiomycetes class, Onygenales order, and Onygenaceae family [40]. The two main species reside in the soil of certain parts of the Western Hemisphere [41]. Coccidioidomycosis is primarily transmitted via respiratory inhalation of airborne arthroconidia, the inhalation of a single spore may be enough to cause illness, but higher spore burdens are more likely to result in significant disease and may precipitate acute respiratory distress syndrome (ARDS) [42].

In addition to residency or travel in endemic areas, immunocompromised people by advancing age, pregnancy, cancer (especially chronic lymphocytic leukemia and nonHodgkin lymphoma), corticosteroid therapy, diabetes, organ transplantation, or human immunodeficiency virus (HIV) infection are at significantly increased risks of contracting coccidioidomycosis [43]. Although most infected individuals do not develop any symptoms, the rest have symptoms ranging from fever, fatigue, cough, dyspnea, chest pain, and pneumonia with severe and life-threatening complications [44]. Additionally, if the infection becomes extrapulmonary, medical intervention may be necessary. Infections can disseminate to the spleen, liver, brain, bone, and many other tissues in the body [45].

\subsection{Mucormycosis}

Mucormycosis is an emerging life-threatening infection caused by various fungal species of the order Mucorales [46]. Rhizopus and Mucor represent the most common agents inducing this lethal infection [29]. Rhizopus is a group in the fungi kingdom that belongs to the Mucoromycota phylum, Mucoromycetes class, Mucorales order, Rhizopodaceae family, Rhizopus genus, and species: microsporus and delemar. On the other hand, Mucor is a genus of mold. It is a member of the kingdom fungi, Mucoromycetes class, Mucorales order, and Mucoraceae family [32]. The Mucorales exhibit fast growth and produce a high number of asexual spores. Humans are frequently exposed to Mucorales spores via inhalation, ingestion, or direct inoculation into a disrupted skin or an open wound [47]. Among the common clinical forms are rhinoorbital/cerebral, pulmonary, renal, gastrointestinal, cutaneous, and disseminated disease [47]. The common risk factors enabling the development of mucormycosis include uncontrolled diabetes mellitus, cancer, solid organ or bone marrow transplantation, hematological malignancy, corticosteroid treatment, and trauma and burns [48].

In recent years, an evolution in mucormycosis epidemiology has been observed with the emergence of new risk factors worldwide, including coronavirus disease (COVID-19) [49]. 
The COVID-19 disease pattern may differ with the severity of the disease; it can range from mild to life-threatening pneumonia with associated bacterial and fungal coinfections. Thus, people with related comorbidities and immunocompromised conditions are more likely to develop severe opportunistic infections [50]. Increasing cases of mucormycosis in patients with COVID-19 have recently been reported worldwide and in India [50-52].

\subsection{Candidiasis (Candida auris)}

Candida spp. is a diploid fungus considered an opportunistic pathogen capable of causing serious infections and compromising human health, especially in individuals with weak immune systems [31,53]. Candidiasis represents the fourth nosocomial infection with a 35 to $100 \%$ mortality rate in immunosuppressed patients [53]. Among the main types of disease generated by Candida include cutaneous, oropharyngeal, candidemia, vaginitis, and systemic infections [31,53]. Recent data reveals that other species and Candida albicans (C. albicans) can also cause infections. Candida auris (C. auris) is an emerging pathogenic species, distributed in almost all continents, which has attracted considerable attention due to its pathogenicity, high resistance to traditional antifungals, and rapid transmission [54]. C. auris belongs to the phylum Ascomycota and is part of the Saccharomycetes class. It is included in the Clavispora/Candida clade that belongs to the Saccharomycetales order, Metschnikowiaceae family, and Clavispora genus [55]. Recent reports indicate that most C. auris isolates are resistant to fluconazole, amphotericin B, and echinocandins; probably, this phenomenon is the result of the uncontrolled and prolonged use of existing use antifungals [56,57]. Furthermore, the transition from blastoconidia to filamentous growth, hydrolytic enzymes, osmotolerance, biofilm formation, cell adhesion, thermotolerance, and the change from white to opaque are some of the virulence traits that contribute substantially to the pathogenesis of $C$. auris $[54,55,58]$.

In addition, it has been observed that this new species of Candida can survive for prolonged times on different environmental surfaces, as well as to disinfectants [31,55,59]. All these characteristics mentioned above allow $C$. auris to adapt and survive the various existing treatments and successfully establish an infection in a patient $[31,54]$. The development of new nanoparticle-based antifungals is a potential way to combat infections caused by species of the Candida genus.

\section{The Current Treatment}

The antifungal agents currently available for treating systemic fungal infections are amphotericin B and liposomal preparations (lipid complexes and liposomes) of amphotericin B; azoles, specially triazoles: fluconazole, itraconazole, voriconazole, posaconazole, and isavuconazole; and echinocandins [4]. Table 2 presents the recommendations for the treatment of fungal infections caused by filamentous fungi.

\subsection{Aspergillosis}

There are three classes of antifungal agents available to treat aspergillosis: polyenes, azoles, and echinocandins. The first-line treatment drug is voriconazole, followed by liposomal amphotericin B (AmB). From these, Itraconazole, voriconazole, and posaconazole are widely used for the treatment of Aspergillus infections. Itraconazole, posaconazole, and echinocandins are primarily used in patients with intolerance of the primary antifungal therapy. Posaconazole is also used for prophylaxis against fungal infections in patients at risk. Despite this, triazole drugs-resistance in several Aspergillus species is emerging continuously [60]. Mortality related to infection caused by azole-resistant fungi rises from 30-50 to $88 \%$ compared with sensitive strains [61]. Currently, the use of AmB or a combination of voriconazole or posaconazole with an echinocandin may be effective for treating Aspergillus infections, as azoles play a limited role in the treatment of this kind of infection [60]. 


\subsection{Coccidioidomycosis}

The selection of the antifungal agent depends on the infection site, the severity of the disease, and the condition of the patient, especially in those who, at the time of diagnosis, have a significantly debilitating illness [62]. Oral azole therapy is the most recommended antifungal treatment (fluconazole, itraconazole, posaconazole, voriconazole, isavuconazole). Fluconazole has become the most utilized primary therapy because it is well absorbed, has fewer drug interactions, and is less expensive than other azole options [63]. Unfortunately, adverse effects from triazoles are hepatotoxicity and cardiac toxicity due to prolongation of the QTc. Furthermore, alopecia, xerosis, and cheilitis are the most frequent side effects of fluconazole, but these follow reversible discontinuation of therapy [64]. Additionally, the overprescription of fluconazole by physicians led to an increase in resistance to azole drugs. Antifungal drug resistance appears to be due to point mutations in either drug targets or transcription factors regulating agents of the resistance [65].

Amphotericin B is used in patients with severe coccidioidomycosis infections or those who clinically fail initial therapy with oral azoles [60]. Conventional amphotericin B deoxycholate is associated with dose-limited toxicities, infusion-related reactions, and nephrotoxicity [66]. Consequently, extensive efforts have been made to reformulate amphotericin B. Considering its lipophilic properties that enable the drug's encapsulation into liposomes or binding to lipid complexes [67].

\subsection{Mucormycosis}

The treatment of mucormycosis is challenging. It involves multiple strategies like removing the infected tissue or partially infected organs, the early administration of an optimal dose of active antifungal agent, and the utilization of different adjunctive therapies [48]. Therefore, early diagnosis is crucial to promptly initiate therapeutic interventions necessary to prevent progressive tissue invasion and its devastating sequelae, minimize the effect of disfiguring corrective surgery, and improve outcome and survival [68].

Currently, few systemic antifungals have been documented as anti-Mucorales, which mostly lack specificity and effectiveness against Mucorales. Amphotericin B (amphotericin B deoxycholate, liposomal amphotericin B, amphotericin B lipid, complex, and lipid-based amphotericin $B$ ) is the first choice for the management of mucormycosis. Lipid formulations of amphotericin $B$ have a better therapeutic index than the conventional amphotericin $B$ deoxycholate; however, the optimal dosage, infusion-related side effects, and high risk of nephrotoxicity are significant potentially therapy-limiting effects [46]. Posaconazole is the second effective antifungal agent followed by novel members of the azole group (triazole) like isavuconazole. Clinical studies on the efficacy of posaconazole for mucormycosis are scarce. Posaconazole could be an option as salvage therapy in patients unresponsive or intolerant to liposomal amphotericin B [69]. Isavuconazole offers some advantages, including good tolerability, a lower side effect profile, excellent bioavailability, and reduced drug-drug interaction but updated guidelines on mucormycosis are needed to reflect the current evidence and give guidance on the use of isavuconazole for this disease [70]. Thus, new strategies to prevent and promptly treat mucormycosis are urgently needed.

\subsection{Candidiasis (Candida auris)}

The main challenge to fight $C$. auris infections is the intrinsic resistance to one or more classes of marketed antifungal drugs. Most isolates of $C$. auris are highly resistant to fluconazole, but the determination of MIC also showed that some strains are resistant to all available classes of antifungal drugs [54]. Optimal treatment against C. Auris is not yet defined. A suggested initial therapy is the use of echinocandins, as most isolates in the United States have been susceptible to this antibiotic class [71-73]. Moreover, although resistant to azoles, isavuconazole was found active against a variety of $C$. auris isolates [73]. 
Table 2. Recommendations for the treatment of fungal infections caused by filamentous fungi and Candida auris.

\begin{tabular}{ccc}
\hline Disease & Current Treatment & References \\
\hline Aspergillosis & $\begin{array}{r}\text { Amphotericin B, azoles (voriconazole, posaconazole, } \\
\text { and itraconazole), and echinocandins. }\end{array}$ & {$[60,61]$} \\
\hline Coccidioidomycosis & $\begin{array}{c}\text { Azoles (fluconazole, itraconazole, posaconazole, } \\
\text { voriconazole, isavuconazole) and amphotericin B. }\end{array}$ & {$[63,74]$} \\
\hline Mucormycosis & Amphotericin B, posaconazole, and isavuconazole. & {$[69,70,75]$} \\
\hline $\begin{array}{c}\text { Candidiasis } \\
\text { (Candida auris) }\end{array}$ & $\begin{array}{r}\text { Echinocandins (caspofungin, micafungin, and } \\
\text { anidulafungin) and isavuconazole }\end{array}$ & {$[71-73]$} \\
\hline
\end{tabular}

\section{Nanotechnology in Antifungal Therapy}

Nanoparticles (NPs) comprise a wide variety of particles with size at the nanoscale level that generally ranges from 1 to $100 \mathrm{~nm}[76,77]$. These particles can be of different shapes and structures, for instance, cylindrical, spherical, tubular, conical, or spiral [77,78]. Currently, NPs have gained the attention of the scientific community due to their multiple potential therapeutic and diagnostic applications, such as in drugs delivery, and as a detection system for biological and chemical agents, among others [79-81]. In addition, these types of materials are considered excellent therapeutic alternatives because they present less toxicity, overcome multiple biological barriers, and can be covalently conjugated with hydrophobic or hydrophilic drugs and macromolecules, improving solubility and stability [81-83].

Considering the shape, size, and chemical and physical properties, nanoparticles can be classified as organic or polymeric, inorganic (metallic), and carbon nanoparticles [77,84]. Organic NPs, including liposomes, micelles, dendrimers, are biodegradable, not toxic, and are sensitive to heat and light [77,85]. Generally, this class of NPs represents the first choice in the biomedical area, mainly for drug delivery, due to their high efficiency and injection on specific sites $[77,81,84]$. Inorganic NPs integrate all those particles synthesized from metals and metal oxides. Metal nanoparticles can be commonly derived from Cadmium $(\mathrm{Cd})$, Aluminum (Al), Cobalt (Co), Copper $(\mathrm{Cu})$, Gold $(\mathrm{Au})$, Iron $(\mathrm{Fe})$, Silver $(\mathrm{Ag})$, and Zinc (Zn) [77,84]. Meanwhile, metal oxide NPs result from modifying the metal particles properties in the oxygen presence, increasing their reactivity and efficiency [77,84]. Among the main metal oxide nanoparticles are aluminum oxide $\left(\mathrm{Al}_{2} \mathrm{O}_{3}\right)$, iron oxide $\left(\mathrm{Fe}_{2} \mathrm{O}_{3}\right)$, titanium oxide $\left(\mathrm{TiO}_{2}\right)$, and zinc oxide $(\mathrm{ZnO})$. Carbon nanoparticles are particles entirely synthesized carbon and classified into fullerenes, graphene, carbon nanotubes, carbon nanofibers, black carbon, and activated carbon $[77,81,84]$.

\subsection{Aspergillosis}

Different research groups continuously study new alternatives. A promising strategy used to fight this problem is nanotechnology. An advantage of using nanomaterials is the increased surface area to volume ratio to interact with microorganisms. From metallic nanoparticles to nanoparticles made of polymers, the use of nanomaterials could lead to a variety of antimicrobial effects due to the synthesis method. Because of this, studying the antimicrobial effect of a certain nanomaterial is of utmost importance to increase the possibilities for treating microbial infections.

\subsubsection{Metal Nanoparticles}

As an alternative to classic drugs used to fight fungal infections, the search for new treatments has become necessary. Like those made from $\mathrm{Ag}, \mathrm{Au}, \mathrm{ZnO}$, and $\mathrm{TiO}_{2}$, metal nanoparticles have great potential to be used as antimicrobial agents against various microorganisms, from bacteria to fungi [17,86-91]. These metallic nanoparticles are continuously studied to overcome microbial infections/growth. Auyeung et al. [33] studied the antimold activity of commercial NPs (metallic-, Ag, Au, and ZnO NPs) against two 
Aspergillus strains, both alone and in combination as well as in paint formulations under fluorescent light. They observed that A. flavus showed resistance to Ag-, Au-, and a combination of metallic: Ag-NPs, but was inhibited when using metallic-NPs $(100 \mu \mathrm{g} / \mathrm{mL}), \mathrm{ZnO}$ NPs $(20 \mu \mathrm{g} / \mathrm{mL})$, and metallic: ZnO NPs $(50: 10 \mu \mathrm{g} / \mathrm{mL})$. A. fumigatus showed resistance to $\mathrm{Au}$ - and metallic: Ag-NPs, and inhibition using Ag-NPs $(10 \mu \mathrm{g} / \mathrm{mL})$, metallic-NPs $(100 \mu \mathrm{g} / \mathrm{mL}), \mathrm{ZnO}$ NPs $(20 \mu \mathrm{g} / \mathrm{mL})$, and metallic: ZnO NPs $(50: 10 \mu \mathrm{g} / \mathrm{mL})$. When $\mathrm{ZnO}$, metallic- and metallic: $\mathrm{ZnO}$ NPs were used in paint formulations, the combination showed an antifungal activity such as amphotericin $\mathrm{B}(\mathrm{AmB}$, used as control) at half the concentration used individually, suggesting an enhanced activity when used in combination. In the study, the presence of fluorescent light generated free radicals that reacted with $\mathrm{O}_{2}, \mathrm{H}_{2} \mathrm{O}$, and $\mathrm{CO}_{2}$ surrounding the fungi generating toxic reactive oxygen species (ROS) damaging protein, lipid, and DNA. Moreover, the authors reported that these NPs showed no toxicity in vitro against human-derived macrophages THP-1 at concentrations up to $400 \mu \mathrm{g} / \mathrm{mL}$. In another study with commercial NPs, Ogar et al. [92] tested marketed AgNPs against various fungal species, including A. fumigatus. Treatment with $100 \mathrm{mg} / \mathrm{L}$ caused A. fumigatus to grow $54 \%$ compared with $100 \%$ of control. In a similar study, $\mathrm{Xu}$ et al. [93] assessed the antifungal activity of marketed AgNPs against various Aspergillus species isolated from patients with fungal keratitis. The mean $\mathrm{MIC}_{90}$ of these AgNPs were 1, 0.5, 0.5 , and $0.5 \mu \mathrm{g} / \mathrm{mL}$ against $A$. flavus (61 isolates), A. fumigatus (11 isolates), A. versicolor (12 isolates), and A. niger (10 isolates), significantly lower than natamycin MICs of 32, 4, 32, and $8 \mu \mathrm{g} / \mathrm{mL}$, respectively.

\subsubsection{Organic Materials-Based Nanoparticles}

An essential parameter in synthesizing metallic nanoparticles for use as antimicrobial agents is the methodology used, which has a strong influence on the therapeutic properties of the NP. Because of this, the molecules/organisms used to control particle dimensions and self-organization is very important. Sayed et al. [94] synthesized two novel spinel nanoferrites $\left(\mathrm{Ag}_{2} \mathrm{Fe}_{2} \mathrm{O}_{4}\right.$ and $\left.\mathrm{Ag}_{2} \mathrm{Cr}_{2} \mathrm{O}_{4}\right)$ by flash auto-combustion to test their antifungal activity against four Aspergillus species. At a $100 \mathrm{mg} / \mathrm{mL}$ concentration compared with fluconazole, $\mathrm{Ag}_{2} \mathrm{Fe}_{2} \mathrm{O}_{2}$ nanoferrite exhibited 1-, 0.8-, and 0.9-times lower inhibition zones against $A$. flavus, A. fumigatus, and $A$. niger, respectively. On the contrary, $\mathrm{Ag}_{2} \mathrm{Cr}_{2} \mathrm{O}_{4}$ showed 3-, 3.1-, and 2.6-times higher inhibition zones against A. flavus, A. fumigatus, A. niger, respectively. This behavior was also observed in the MIC determinations, where $\mathrm{Ag}_{2} \mathrm{Fe}_{2} \mathrm{O}_{2}$ antifungal effects were observed at $50 \mathrm{mg} / \mathrm{mL}, \mathrm{Ag}_{2} \mathrm{Cr}_{2} \mathrm{O}_{4}$ at $12.5 \mathrm{mg} / \mathrm{mL}$, and fluconazole at $25 \mathrm{mg} / \mathrm{mL}$ against all four fungal species. Dilshad et al. [74] observed the antimicrobial effect of citric acid- and maleic acid-capped AgNPs against $A$. niger, A. flavus, A. fumigatus, and Fusarium solani. The authors observed that the maleic acid-capped NPs exhibit better antifungal activity than citric acid-capped NPs. The difference could be caused by their smaller size and round shape, resulting in more surface area interacting with the fungi strains than the citric acid NPs with larger size and rough flower shape. Furthermore, NPs of smaller sizes release more silver ions $\left(\mathrm{Ag}^{+}\right)$than larger particles and kill more pathogens than the latter. Pandey et al. [95] synthesized AgNPs stabilized by milk proteins and tested against $A$. fumigatus and $A$. ochraceus. Milk protein synthesized AgNPs showed a higher antifungal effect against $A$. ochraceus than $A$. fumigatus at a concentration of $400 \mu \mathrm{g} /$ disk. Selvaraj et al. [96] used a complex of 5-fluorouracil (5FU) with AuNPs (Au@5FU) for antifungal tests against $A$. niger and $A$. fumigatus. In comparison with 5FU, Au@5FU NPs showed higher inhibition zones against $A$. niger $(19 \mathrm{~mm} 5 \mathrm{FU}, 29 \mathrm{~mm}$ Au@5FU) and A. fumigatus (23 mm 5FU, 32 mm Au@5FU). Similarly, Selvaraj et al. [96] used a complex of 5-fluorouracil (5FU) with AuNPs (Au@5FU) for antifungal tests against A. niger and A. fumigatus. In comparison with 5FU, Au@5FU NPs showed higher inhibition zones against $A$. niger (19 mm 5FU, $29 \mathrm{~mm} \mathrm{Au@5FU)} \mathrm{and} \mathrm{A.} \mathrm{fumigatus} \mathrm{(23} \mathrm{mm} \mathrm{5FU,}$ $32 \mathrm{~mm} \mathrm{Au@5FU).}$

Metal nanoparticles can be added to various polymers, forming composites, increasing, or giving new properties to the polymer, such as preventing growth or adherence of harmful 
microorganisms [18]. In this regard, Fonseca et al. [97] studied the antimicrobial properties of poly(lactic acid) (PLA) composite with $\mathrm{TiO}_{2}$ NPs. They observed that light conditions have an essential role in the antifungal property of the nanocomposite. Under white light, PLA nanocomposite reduced fungal growth at 9.2 and $52.6 \%$ with 5 and 8 wt.\% of NPs, respectively. This fungal reduction increased to 66.7 and $99.9 \%$, with 5 and $8 \mathrm{wt}$ \% of NPs, respectively, when nanocomposites were exposed to ultraviolet (UVA) irradiation. Although nanocomposites presented good antimicrobial activity in the absence of irradiation, the induction of photocatalysis caused by UVA could increase the antifungal effect due to ROS generation and subsequent decomposition of the cell membrane. Leudjo Taka et al. [98] synthesized a nanosponge composite of polyurethane cyclodextrin copolymerized phosphorylated multiwalled carbon nanotube-doped $\mathrm{Ag}-\mathrm{TiO}_{2}$ nanoparticle (pMWCNT-CD/Ag-TiO ${ }_{2}$ ) and evaluated its antifungal effect against two Aspergillus strains. This nanocomposite had a MIC of $437.5 \mu \mathrm{g} / \mathrm{mL}$ against both $A$. ochraceus and $A$. fumigatus, and this value has lower than the nanosponge without dopped NPs, $1750 \mu \mathrm{g} / \mathrm{mL}$. The antifungal effect is attributed to the functional groups of the fungus membrane interacting with the nanocomposite, leading to ROS production and disruption of cell wall membrane, as a probable effect of the $\mathrm{TiO}_{2}$ and Ag NPs dopped to the material. Mane et al. [99] synthesized Ag and Au nanocomposites using fibroin (FSNC and FGNC, respectively) obtained from Bombyx mori. The synthesized nanocomposites containing Ag or Au NPs showed good antifungal activity compared to fibroin material alone when applied in a disk diffusion test against $A$. fumigatus. The minimum fungicidal concentration was tested, resulting in 2 and $10 \mu \mathrm{g} / \mathrm{mL}$ for FSNC and FGNC, respectively. Additionally, the authors report that both FSNC and FGNC could enhance leakage of cellular components like proteins, reducing sugars, DNA and RNA. Sabira et al. [100] tested the antifungal activity of two core-shell bimetallic nanoparticles $(\mathrm{Cu}-\mathrm{Ag}$ and $\mathrm{Ag}-\mathrm{Cu})$ synthesized using polyvinyl alcohol (PVA) matrix. In this study, Cu-Ag core-shell NPs exhibited a better antifungal activity against $A$. fumigatus than $\mathrm{Ag}-\mathrm{Cu}$ NPs, causing an inhibition zone of 23 and $16 \mathrm{~mm}$, respectively, at $0.1 \mathrm{M}$. Contrarily, $\mathrm{Ag}-\mathrm{Cu}$ showed a better fungicidal effect than $\mathrm{Cu}-\mathrm{Ag}$ with minimum fungicidal concentration (MFC) of 15 and $25 \mu \mathrm{g} / \mathrm{mL}$, respectively, also causing damage in fungal cell wall as observed by scanning electron microscope (SEM) images. Colloidal AgNPs contained in cross-linked chitosan biguanidine (CChG/AgNPs) were tested as antifungal nanocomposite against fungi species, included $A$. fumigatus by Slama et al. [101]. Compared with the formulation without AgNPs, CChG/AgNPs showed better antifungal activity in NPs containing matter and showed almost the same inhibition zone as AmB (22.1 and $23.7 \mathrm{~mm}$, respectively), both at $0.98 \mu \mathrm{g} / \mathrm{mL}$. Moreover, this nanocomposite showed no toxicity in vitro when used in the MCF-7 cell line.

\subsubsection{Plant Extracts-Based Nanoparticles}

As a green synthesis method, the use of plant extracts as reducing/capping agents is widely studied due to their low cost and environmental toxicity [23,91,102]. With a leaf extract of Prunus cerasifera, Jaffri et al. [103] studied the synthesis of ZnO NPs and their antifungal activity against drug-resistant Aspergillus strains. ZnO NPs synthesized with $P$. cerasifera leaf extract showed good growth inhibition of resistant Aspergillus strains. When using $10 \mu \mathrm{L}, \mathrm{ZnO}$ NPs caused zones of inhibition of 21.05, 23.04, 19.02, and $14.01 \mathrm{~mm}$ against $A$. niger, $A$. flavus, $A$. fumigatus, and $A$. terreus, respectively. These zones of inhibition were higher than the obtained when using AmB against all resistant strains. Here, the authors suggest that the antifungal effect can be attributed to the generation of surface ROS and subsequent oxidative stress. Khan et al. [104] synthesized ZnO NPs using an extract of Trianthema prtulacastrum as a reducing agent and tested it as an antifungal agent against Aspergillus strains. $100 \mu \mathrm{g} / \mathrm{mL}$ of ZnO NPs inhibited the growth of A. niger, A. flavus, and A. fumigatus by 45,41 , and $51 \%$, respectively. These ZnO NPs caused no toxic effect against MC3T3-E1 cells, showing promising results for using the synthesized NPs to treat fungal infections. Using paper wasp (Polister sp) nest's extract as a reducing agent for the synthesis of AgNPs, Lateef et al. [105] tested their antimicrobial activity against Aspergillus strains. 
AgNPs showed complete growth inhibition of A. niger and A. flavus at 100 and $150 \mu \mathrm{g} / \mathrm{mL}$; meanwhile, at these concentrations, A. fumigatus was inhibited by $75.61 \%$. In another study, Lateef et al. [106] synthesized AgNPs using Petiveria alliacea leaf extract and tested similar properties to the synthesized with a wasp nest. Here, the leaf extract synthesized AgNPs showed complete inhibition of A. flavus and A. fumigatus, but only $66.67 \%$ growth inhibition of $A$. niger. In addition, these NPs were tested for anticoagulant and thrombolytic activity. The leaf extract-synthesized AgNPs showed good anticoagulant activity. Meanwhile, using wasp nest showed suitable anticoagulant and thrombolytic activity, suggesting that these AgNPs are useful for fighting fungal infections and various biomedical applications.

\subsubsection{Nanoparticles Obtained from Prokaryotic/Eukaryotic Cultures}

A variety of prokaryotic/eukaryotic cell cultures are widely studied for the green synthesis of NPs. El Sayed et al. [107] used F. solani culture as a synthesis medium of metal NPs $(\mathrm{Ag}, \mathrm{Cu}$, and $\mathrm{ZnO})$. They evaluated their activity against clinical isolates of A. awamori, A. fumigatus, and Fusarium oxysporum. The MIC obtained for each NP was 40 and $43.3 \mu \mathrm{g} / \mathrm{mL}$ for AgNPs, 31.67 and $41.60 \mu \mathrm{g} / \mathrm{mL}$ for CuNPs, and $26.7 \mathrm{and} 28.3 \mu \mathrm{g} / \mathrm{mL}$ $\mathrm{ZnO}$ NPs against $A$. awamori and $A$. fumigatus, respectively. Similarly, using the diskdiffusion test, $\mathrm{Ag}-, \mathrm{Cu}-$, and $\mathrm{ZnO}$ NPs showed higher inhibition zones against $A$. awamori than A. fumigatus. However, ZnO NPs showed the highest inhibition zone than Ag- and CuNPs at the same concentration. This effect can be caused due to the destruction of cell membrane integrity by the abrasive surface of Zn ONPs and ROS production [108]. Using Penicillium expansum culture as a synthesis method for the obtention of Se NPs, Hashem et al. [109] studied the effect of these NPs against some Aspergillus strains. The authors report the MIC of Se NPs as $250 \mu \mathrm{g} / \mathrm{mL}$ with an inhibition zone of 10.4 and $11 \mathrm{~mm}$ for $A$. fumigatus and $A$. niger, respectively, possibly caused by Se NPs interaction with the cell membrane, leading to physical damage and leakage of cellular compounds. Similarly, Khan et al. [110] synthesized AgNPs from Bacillus sp. MB353 culture and tested against A. niger, A. fumigatus, and $F$. soleni. These AgNPs showed good antifungal activity against $A$. niger, causing $94 \%$ growth inhibition at $50 \mu \mathrm{g} / \mathrm{mL}$, but only $60 \%$ growth inhibition against $A$. fumigatus and $74 \%$ against $F$. soleni at the same concentration. Unfortunately, these AgNPs showed high cytotoxicity at $25 \mu \mathrm{g} / \mathrm{mL}$, with cell death rates of $88 \%$ against human fibroblast cells, limiting the use of these NPs to treat fungal infections. Using a cell-free extract of Bacillus safensis LAU 13, Ojo et al. [111] synthesized Ag and Ag-Au NPs and evaluated their antifungal activity. The monometallic NPs caused 66.67 and $75.32 \%$ of growth inhibition against $A$. niger and A. fumigatus, respectively, at $200 \mu \mathrm{g} / \mathrm{mL}$. Ag-Au NPs caused 83.33 and $90.78 \%$ inhibition against $A$. niger and $A$. fumigatus, suggesting that bimetallic nanoparticles could be more potent than monometallic NPs. This antifungal effect could be attributed to damage to the cell wall. Shakibaie et al. [112] synthesized Se NPs in a Bacillus sp. MSh- 1 culture for its use as an antifungal agent against $A$. fumigatus. These Se NPs exhibited a MIC value of $100 \mu \mathrm{g} / \mathrm{mL}$ against $A$. fumigatus using the broth dilution method. In another study using a Streptomyces sp. VITSTK7 filtrate, Thenmozhi et al. [113] synthesized $\mathrm{AgO} / \mathrm{Ag}$ NPs to use them as antifungal agents against Aspergillus pathogens. AgO/Ag NPs at a $50 \mu \mathrm{g} / \mathrm{mL}$ concentration showed significant antifungal, causing inhibition of $75.25,67.22$, and $62.30 \%$ against $A$. fumigatus, A. niger, and A. flavus respectively. The antifungal activity of these $\mathrm{AgO} / \mathrm{Ag}$ NPs may be caused by a reduction in spore's production as $A$. niger spores were not produced after prolonged incubation with the NPs.

\subsubsection{Nanoparticles-Based Drug Delivery or Controlled Drug Release Systems}

Nano-formulation of conventional antifungal compounds is advantageous to control the release of the active ingredient by manipulating the outer shell of the nano-capsules, leading to better treatment of various diseases. Roy et al. [114] synthesized nanocomposites of polyethylene glycol (PEG) containing hexaconazole (N-Hexa). The resulted nanocomposite was tested against two A. niger strains and one A. fumigatus strain. After $48 \mathrm{~h}, \mathrm{~N}-\mathrm{Hexa}$ 
caused a reduction of fungal growth from 26 to 9 and $4 \mathrm{~mm}$ for $A$. niger species, at 5 and $10 \mathrm{ppm}$, respectively, and a reduction from 20 to 3 and $1 \mathrm{~mm}$ for A. fumigatus. Authors reported that incorporating hexaconazole to PEG increased its water solubility, leading to a better antifungal effect than a non-encapsulated formulation. Furthermore, due to the poor bioavailability of currently approved drugs, the use of different drug delivery technology, such as hydrogels, micro-particles, NPs, and liposomes, has been proposed to enhance bioavailability and prolonged drug release. Bhatta et al. [115] studied mucoadhesive lecithin/chitosan (L/C) NPs as new drug delivery for natamycin, for antifungal activity against $C$. albicans and $A$. fumigatus compared with natamycin alone and a commercial ophthalmic suspension. The authors reported similar MIC of NPs compared with commercial suspension and natamycin when used 10, 25, and $50 \mu \mathrm{g}$ of the active compound. The NPs, although they presented lower inhibition than natamycin, showed higher zones of inhibition when compared with the commercial formulation. In addition, the authors reported no ocular damage or clinically abnormal signs in the cornea when NPs were tested using an in vivo rabbit model. In another study, Chhonker et al. [116] proposed using L/C NPs as a drug delivery system for amphotericin B and its antifungal activity against $A$. fumigatus clinical isolate. L/C NPs showed a MIC of $0.12 \mu \mathrm{g} / \mathrm{mL}$ against $A$. fumigatus; meanwhile, AmB MIC was $0.06 \mu \mathrm{g} / \mathrm{mL}$ and Fungizone ${ }^{\circledR}$, a commercial formulation, $0.25 \mu \mathrm{g} / \mathrm{mL}$. Authors suggest that the difference between AmB and NPs is because of the restricted drug release caused by the L/C matrix. AmB caused a higher zone of inhibition, but NPs and commercial formulation showed no significant difference. These studies suggest that L/C NPs, used as drug delivery systems, are comparable to marketed ophthalmic suspension by showing no differences in antifungal effects. Malhotra et al. [117] encapsulated fluconazole analogs in O-alkylated dextran nanoparticles as a drug delivery system to characterize its antifungal effect against $A$. fumigatus. The analog encapsulated in O-decyl-derivatized NPs inhibited the growth of $A$. fumigatus at an effective concentration of $3.16 \mu \mathrm{g} / \mathrm{mL}$. Moreover, when the analog was encapsulated in O-hexadecyl NPs, the growth inhibition was achieved at an effective concentration of $1.63 \mu \mathrm{g} / \mathrm{mL}$. These inhibitory concentrations were lower than both fluconazole and its analog alone. Here, the encapsulated form has more efficient uptake by the fungus, needing lower antifungal concentration. The authors also reported minimal in vitro cytotoxicity against human erythrocytes and cell lines at antifungal concentrations. AmB was entrapped in lipid NPs (LNPs) as a nanoscale drug carrier in a study made by Jung et al. [75] to compare its antifungal effect against fluconazole-resistant A. fumigatus to two commercial AmB formulations (Fungizone ${ }^{\circledR}$ and AmBisome ${ }^{\circledR}$ ) both in vitro and in vivo. Here, the AmB-entrapping LNPs showed no better in vitro antifungal activity than AmBisome ${ }^{\circledR}$ but higher activity than Fungizone ${ }^{\circledR}$, with MICs of $0.025,0.25$, and $1 \mu \mathrm{g} / \mathrm{mL}$ for LNPs, AmBisome ${ }^{\circledR}$, and Fungizone ${ }^{\circledR}$, respectively. Meanwhile, in an in vivo immunosuppressed mice infection model using A. fumigatus, AmB-entrapped LNPs showed higher survival rates than AmBisome. These results are consistent with other reports where liposomal and free $\mathrm{AmB}$ has comparable antifungal activities against various fungi [118]. Van de Ven et al. [119] studied the antifungal in vitro and in vivo effect of AmB-loaded poly(D, L-lactide-co-glycolide (PLGA) NPs against various fungal pathogens, including $A$. fumigatus. In vitro, AmB-loaded PLGA NPs showed significantly higher antifungal activity against $A$. fumigatus than $\mathrm{AmB}$, Fungizone ${ }^{\circledR}$, and AmBisome ${ }^{\circledR}\left(\mathrm{IC}_{50}\right.$ of $<0.03,0.93,0.39$, and $0.63 \mu \mathrm{g} / \mathrm{mL}$, respectively), as well as lower cytotoxicity against MRC -5 cells $\left(\mathrm{CC}_{50}\right.$ of $>64,26.4,54.3$, and $>64 \mu \mathrm{g} / \mathrm{mL}$, respectively) and lower hemolytic activity against red blood cells $\left(\mathrm{HC}_{50}\right.$ of $>64,4.9,18.3$, and $>64 \mu \mathrm{g} / \mathrm{mL}$, respectively). Similarly, the AmB-loaded PLGA NPs caused a significant reduction of $A$. fumigatus compared with Fungizone ${ }^{\circledR}$ and a 2-times more efficient reduction than AmBisome when used in vivo at a dosage of $5 \mathrm{mg} / \mathrm{kg}$. Shirkhani et al. [120] used nebulized-AmB/polymethacrylic acid (AmB-PMA) nanoparticles as a prophylaxis treatment to prevent invasive aspergillosis. In vitro assay with $A$. fumigatus showed that AmB-PMA NPs caused total inhibition of the fungi at $300 \mu \mathrm{g}$ of AmB in PMA. Similarly, using AmB-PMA NPs at a dose of $300 \mu \mathrm{g}$ of AmB in PMA in vivo, total inhibition of fungal growth from the lungs of infected BLAB/c mice 
at day +2 of infection was observed. Khames et al. [121] prepared natamycin solid lipid nanoparticles (SLNs). These SLNs were tested against $A$. fumigatus, causing an increase in the inhibition zone by $8 \mathrm{~mm}$ compared to natamycin alone (18 to $26 \mathrm{~mm}$ ). The MIC measured by broth dilution assay showed a reduction of 2.5 times when natamycin was used in SLNs. Furthermore, ex vivo histopathological studies showed no sign of irritation or morphological changes of the corneal epithelium. Lakhani et al. [122] synthesized AmB loaded PEGylated nanostructures lipid carriers (AmB-PEG-NLC) for a better ocular biodistribution after topical instillation. The antifungal activity was tested in vitro against A. fumigatus. AmB-PEG-NLC showed an MIC of $1.25 \mu \mathrm{g} / \mathrm{mL}$ against Aspergillus, half the concentration of AmB alone $(2.5 \mu \mathrm{g} / \mathrm{mL})$ and the marketed formulations Fungizone ${ }^{\circledR}$ and AmBisome ${ }^{\circledR}$ (0.62 and $1.25 \mu \mathrm{g} / \mathrm{mL}$, respectively). This AmB-PEG-NLC showed no cytotoxicity to ARPE-19 cells at a concentration range of $0.95-30 \mu \mathrm{g} / \mathrm{mL}$, suggesting a good therapeutic index. Moreover, the authors report similar AmB concentration in ocular tissues when using AmB-PEG-NLC or AmBisone ${ }^{\circledR}$ in vivo, making this formulation an alternative for the topical delivery of AmB.

As mentioned, studying the effects of a variety of nanomaterials increases the possibilities for treating aspergillosis. The use of green methodologies increases the bioavailability of metallic nanoparticles. These nanoparticles could be used as delivery systems of various antimicrobial compounds. In addition, the use of nanomaterials made of polymers as delivery systems is comparable to marketed formulations. The studies included here show that nanomaterials could be considered an alternative for treating fungal infections as aspergillosis. A summary of nanomaterials used in the treatment of Aspergillus fumigatus infections is presented in Table 3.

Table 3. Nanomaterials used in the treatment of Aspergillus fumigatus infections.

\begin{tabular}{|c|c|c|}
\hline Nanomaterial & Antifungal Effect & Reference \\
\hline \multirow{6}{*}{ AgNPs } & Growth inhibition at $10 \mu \mathrm{g} / \mathrm{mL}$ & [33] \\
\hline & $54 \%$ growth inhibition at $100 \mathrm{mg} / \mathrm{L}$ & [92] \\
\hline & $75.61 \%$ growth inhibition at $150 \mu \mathrm{g} / \mathrm{mL}$ & [105] \\
\hline & Growth inhibition at $150 \mu \mathrm{g} / \mathrm{mL}$ & [106] \\
\hline & Growth inhibition at $40 \mu \mathrm{g} / \mathrm{mL}$ & [107] \\
\hline & $60 \%$ growth inhibition at $50 \mu \mathrm{g} / \mathrm{mL}$ & [110] \\
\hline Marketed AgNPs & $\begin{array}{l}90 \% \text { growth inhibition at } 0.5 \mu \mathrm{g} / \mathrm{mL} \\
\text { (clinical isolates) }\end{array}$ & [93] \\
\hline $\mathrm{AgO} / \mathrm{Ag} \mathrm{NPs}$ & $75.25 \%$ growth inhibition at $50 \mu \mathrm{g} / \mathrm{mL}$ & [113] \\
\hline Ag-AuNPs & $90.78 \%$ growth inhibition at $200 \mu \mathrm{g} / \mathrm{mL}$ & [111] \\
\hline $\mathrm{Ag}_{2} \mathrm{Cr}_{2} \mathrm{O}_{4}$ & $\begin{array}{l}\text { 3.1 times higher inhibition than } \\
\text { fluconazole }\end{array}$ & [94] \\
\hline Maleic acid capped AgNPs & Growth inhibition & [74] \\
\hline Milk protein synthesized AgNPs & Growth inhibition & [95] \\
\hline Fibroin-AgNPs & Fungicidal activity at $2 \mu \mathrm{g} / \mathrm{mL}$ & [99] \\
\hline Ag-Cu core-shell NPs & $\begin{array}{l}\text { Growth inhibition at } 0.1 \mathrm{M} \text { and } \\
\text { fungicidal activity at } 15 \mu \mathrm{g} / \mathrm{mL}\end{array}$ & [100] \\
\hline CChG/AgNPs & $\begin{array}{l}\text { Better growth inhibition than } \mathrm{AmB} \text { at } \\
0.98 \mu \mathrm{g} / \mathrm{mL}\end{array}$ & [101] \\
\hline CuNPs & Growth inhibition at $31.67 \mu \mathrm{g} / \mathrm{mL}$ & [107] \\
\hline $\mathrm{Cu}$-Ag core-shell NPs & $\begin{array}{l}\text { Growth inhibition at } 0.1 \mathrm{M} \text { and fungicidal } \\
\text { activity at } 25 \mu \mathrm{g} / \mathrm{mL}\end{array}$ & [100] \\
\hline Au@5FU NPs & Higher inhibition than 5FU & [96] \\
\hline Fibroin-AuNPs & Fungicidal activity at $10 \mu \mathrm{g} / \mathrm{mL}$ & [99] \\
\hline $\mathrm{TiO}_{2}$-PLA NPs & $99.9 \%$ growth inhibition at $8 w \mathrm{t} \%$ of NPs & [97] \\
\hline $\begin{array}{l}\text { pMWCNT-CD/Ag-TiO } \\
\text { nanosponge }\end{array}$ & Growth inhibition at $437.5 \mu \mathrm{g} / \mathrm{mL}$ & [98] \\
\hline
\end{tabular}


Table 3. Cont.

\begin{tabular}{|c|c|c|}
\hline Nanomaterial & Antifungal Effect & Reference \\
\hline \multirow{4}{*}{ ZnONPs } & Growth inhibition at $20 \mu \mathrm{g} / \mathrm{mL}$ & [33] \\
\hline & $\begin{array}{l}\text { Higher inhibition zone than AmB } \\
\text { (resistant strain) }\end{array}$ & [103] \\
\hline & $51 \%$ growth inhibition at $100 \mu \mathrm{g} / \mathrm{mL}$ & [104] \\
\hline & Growth inhibition at $26.7 \mu \mathrm{g} / \mathrm{mL}$ & [107] \\
\hline \multirow[t]{2}{*}{ SeNPs } & Growth inhibition at $250 \mu \mathrm{g} / \mathrm{mL}$ & [109] \\
\hline & Growth inhibition at $100 \mu \mathrm{g} / \mathrm{mL}$ & [112] \\
\hline N-Hexa & Growth reduction at $10 \mathrm{ppm}$ & {$[114]$} \\
\hline $\begin{array}{l}\text { Natamicyin encapsulated L/C } \\
\text { NPs }\end{array}$ & Similar growth inhibition than natamycin & {$[115]$} \\
\hline AmB encapsulated L/C NPs & Growth inhibition at $0.12 \mu \mathrm{g} / \mathrm{mL}$ & {$[116]$} \\
\hline AmB entrapped lipid NPs & Growth inhibition at $0.025 \mu \mathrm{g} / \mathrm{mL}$ & {$[75]$} \\
\hline AmB loaded PLGA NPs & $50 \%$ growth inhibition at $0.03 \mu \mathrm{g} / \mathrm{mL}$ & [119] \\
\hline AmB-PMA NPs & Growth inhibition with $300 \mu \mathrm{g}$ of AmB & {$[120]$} \\
\hline AmB leaded PEG NLC & Growth inhibition at $1.25 \mu \mathrm{g} / \mathrm{mL}$ & {$[122]$} \\
\hline $\begin{array}{l}\text { Fluconazole encapsulated } \\
\text { O-alkylated dextran }\end{array}$ & Growth inhibition at $3.16 \mu \mathrm{g} / \mathrm{mL}$ & [117] \\
\hline Natamycin SLNPs & Better inhibition zones than natamycin & [121] \\
\hline
\end{tabular}

Abbreviations: CChG: Cross-linked chitosan biguanidine; 5FU: 5-fluorouracil; PLA: poly (lactic acid) pMWCNT-CD: polyurethane cyclodextrin co-polymerized phosphorylated multiwalled carbon nanotube; NHexa: nanocomposite-containing hexaconazole: L/C: lecithin/chitosan; AmB: amphotericin B; PLGA: poly(D, L-lactide-co-glycolide acid; PMA: polymethacrylic acid; PEG-NLC: polyethylene glycol nanostructures lipid carrier; SLNP: solid lipid nanoparticles.

\subsection{Coccidioidomycosis}

A significant impact of nanobiotechnology for new formulations of conventional drugs is the possibility of designing functional drug delivery systems at the nanoscale. Thus, their pharmacokinetic and pharmacodynamics properties can be modified to optimize their pharmacological response [123]. The U.S. Food and Drug Administration has approved the use of AmB nanoformulations to treat systemic fungal infections. Three lipid formulations of amphotericin B have been developed to face its toxicity issues [124]. Amphotericin B lipid complex (ABLC, Abelcet ${ }^{\circledR}$, The Liposome Co., Princeton, NJ, USA) consisting of a microscopic ribbon-like lipid structure; liposomal amphotericin B (L-AmB, AmBisome ${ }^{\circledR}$, Gilead. Sciences, Sandimas, CA, USA) in which the drug is intercalated within the lipid bilayer of cholesterol-containing liposomes; amphotericin B colloidal dispersion (ABCD, Amphote ${ }^{\circledR} /$ Amphocil $^{\circledR}$ ), in which the drug forms disk-shaped lipid structures with sodium cholesteryl sulfate, a naturally occurring cholesterol metabolite $[125,126]$.

In a report by Furebring et al., severe and common side-effects were reported from 19 patients treated with amphotericin B lipid complex (Abelcet) at Huddinge Hospital, Huddinge, Sweden, and at Rigshospitalet, Copenhagen, Denmark. Fourteen patients from 19 discontinued Abelcet mainly due to renal toxicity, increase in bilirubin, erythema, and infusion-related symptoms, such as fever, chills, and severe vomiting. These results suggest that Scandinavian people might be more sensitive to Abelcet than those from the UK and the USA [127].

It has been shown that AmBisome is an effective treatment for coccidioidomycosis in humans [128]. Liposomal AmB has been successfully used as an alternative and safe option in treating disseminated coccidioidomycosis in a patient who was on steroid therapy [129]. In Mexico, a meningeal coccidioidomycosis clinical case was treated with AmBisome for nine months and no liver or kidney toxicity data were reported [130]. Furthermore, AmBisome has been employed in combination with azoles in a rare case of disseminated coccidioidomycosis (with osteomyelitis and compression of the lumbar vertebral body) [131]. 
Clemons et al. (2009) compared the efficacy of Abelcet and AmBisome in coccidioidal meningitis caused by Coccidioides posadasii in rabbits. The treated animals showed few clinical signs of infection, and the number of CFU in the brain and spinal cord was 100- to 10,000 -fold lower than the control group. These data show that both antifungal agents were similarly highly effective [132]. The efficacy and toxicity of amphotericin B lipid complex or liposomal amphotericin B were evaluated in patients with severe coccidioidomycosis infections. A retrospective pre-post study design was conducted in patients between 2005 and 2014. Results showed that both formulations were equally effective in the treatment of this fungal infection. Moreover, AmBisome showed less renal toxicity than Abelcet, and therefore it is preferred to use in patients with baseline renal impairment [66]. Another study also evaluated the efficacy of lipid formulations of amphotericin B (AmB lipid complex, AmB colloidal dispersion, and liposomal AmB) compared to conventional amphotericin B in a murine systemic coccidioidomycosis model. The results demonstrated that conventional amphotericin B was more active than lipid formulations in reducing the fungal burdens. However, lipid formulations could be administrated at higher doses that were well tolerated, achieved sterilization of tissues, and prolonged survival of mice compared with no treated control [133]. Table 4 presents a summary of nanomaterials used in the treatment of Coccidioidomycosis infections.

Table 4. Nanomaterials used in the treatment of Coccidioidomycosis infections.

\begin{tabular}{|c|c|c|}
\hline Nanomaterial & Antifungal Effect & Reference \\
\hline $\begin{array}{c}\text { Amphotericin B lipid complex } \\
\left(\text { ABLC, } \text { Abelcet }^{\circledR}\right)\end{array}$ & Highly effective treatment. & {$[132,133]$} \\
\hline $\begin{array}{l}\text { Liposomal amphotericin B } \\
\quad\left(\mathrm{L}-\mathrm{AmB}, \text { AmBisome }^{\circledR}\right)\end{array}$ & $\begin{array}{l}\text { Successfully used as an alternative } \\
\text { and safe option of treatment. }\end{array}$ & [128-131,133] \\
\hline $\begin{array}{l}\text { Amphotericin B colloidal dispersion } \\
\left(\mathrm{ABCD}, \mathrm{Amphotec}{ }^{\circledR} / \text { Amphocil }^{\circledR}\right)\end{array}$ & $\begin{array}{l}\text { Well tolerated and effective } \\
\text { treatment }\end{array}$ & [133] \\
\hline
\end{tabular}

As we described, coccidioidomycosis is a worrisome public health issue; however, there are some limitations of current treatment in terms of clinical efficacy and efficiency. Therefore, it is of utmost importance to apply nanotechnology for drug development, synthesize new and innovative carriers (nano-based drug delivery systems) beyond the production of amphotericin B liposomal formulations. Thus, the design and development of novel therapeutic alternatives is an emerging need.

\subsection{Mucormycosis}

The Mucorales have developed multi-resistance to current antifungals used to treat the infection, including amphotericin B, posaconazole, and isavuconazole [134-137]. This fact complicates the treatment of the disease. Thus, the development of effective and safe antifungal agents is an urgent need for the appropriate treatment of mucormycosis. The new antifungal therapies generated against some Mucorales species include nanoemulsions NB-201, silver nanoparticles (AgNPs), and zirconium oxide nanoparticles (ZrO2NPs). However, most of them are still in the in vitro experimental phase [138].

Silver formulations have less toxicity to human cells and are highly effective against human pathogens $[90,138]$. Because of this characteristic, the silver nanoparticles have attracted attention against human pathogens [139]. Fungal activity assays revealed the ability of silver nanoparticles encapsulated with $\beta$-cyclodextrin to contend against Mucorales, which caused a reduction in the M. ramosissimus growth [138]. This data proposes silver nanoparticles as a potential antifungal system to stop the course of mucormycosis. However, additional studies, including other Mucorales species, are needed to obtain more information about the antifungal properties of silver nanoparticles $[138,139]$. The zirconium oxide nanoparticles have also emerged as a new antifungal therapy. To date, there are few works on the antifungal activity of zirconium oxide nanoparticles. Still, it has been 
possible to demonstrate their ability to inhibit several Mucor and Rhizopus species [140]. The nanoemulsion NB-201 constitutes another antimycotic therapeutic option. NB-201 contains benzalkonium chloride (BZK) surfactant, which affects the fungal cell membrane killing of the organism [141,142]. BZK lacks toxicity for the human epidermis and is a common component of antiseptic creams and medical consumer products [143]. In vitro susceptibility tests revealed a high ability of NB-201 to reduce the growth of Mucorales, between them various Mucor and Rhizopus isolates (M. circinelloides, R. microsporus and R. delemar) $[142,144]$. This result suggests that nanoemulsion NB-201 can be used as a topical treatment for combating mucormycosis [144]. Table 5 presents a summary of nanomaterials used in the treatment of Mucorales infections.

Table 5. Nanomaterials used in the treatment of Mucorales infections.

\begin{tabular}{clc}
\hline Nanomaterial & Antifungal Effect & Reference \\
\hline Nanoemulsions NB-201 & Growth inhibition & {$[141]$} \\
\hline Silver nanoparticles (AgNPs), & Growth inhibition & {$[138]$} \\
\hline Zirconium oxide nanoparticles (ZrO2NPs) & Growth inhibition & {$[140]$} \\
\hline
\end{tabular}

Nowadays, the relationship between the antifungal properties of nanoparticles and mucormycosis remains poorly characterized. The synthesis of new antifungal drugs is crucial and urgent to counter the high mortality levels from mucormycosis in immunocompromised patients.

\subsection{Candidiasis (Candida auris)}

Currently, various nanoparticle-based antifungal therapies have been developed and are being evaluated against $C$. auris. These types of nanoscale particles constitute a new generation of antifungals and a promising strategy to overcome fungal infections.

Recent data show that silver nanoparticles have activity against nosocomial infections and multi-resistant agents [145-147]. Several research groups have demonstrated a high inhibitory activity of AgNPs on biofilm formation and growth of C. auris [146,148]. AgNPstreated biofilms exhibit a cell wall alteration due to disruption of the C. auris cell wall [146]. Additional analyzes also showed an important activity of AgNPs on medical surfaces (silicone elastomers) and bandage fibers, decreasing the formation of biofilms [146]

In addition, AgNPs-functionalized fibers negatively impact the growth of the fungus even after several washes [146]. On the other hand, $\mathrm{Ag}$-Cu-Co trimetallic nanoparticles exhibited strong fungicidal activity against $C$. auris, causing a reduction in growth, less cell viability, cell arrest, and damage to the mitochondrial membrane inducing the release of apoptotic markers [149]. In addition, these trimetallic particles do not exhibit toxicity and are currently in phase two of in vivo studies [149]. This fact indicates that trimetallic nanoparticles are excellent candidates for the development of antifungal agents [149]. Vazquez-Munoz et al. (2020) analyzed the antimicrobial properties of bismuth nanoparticles (BiNPs), which showed a powerful activity altering cell morphology and biofilm formation. However, further studies of the activity of BiNPs against C. auris are necessary [150].

Recent studies indicate that nanoparticles generating nitric oxide $(\mathrm{NO})$ are capable of eliminating C. auris [151]. This type of nanoparticle was able to suppress the formation of biofilm and planktonic from C. auris isolates used in the study. This fact suggests that nitric oxide nanoparticles appear to be an excellent antifungal candidate to fight against this multidrug-resistant fungus [151]. Table 6 presents a summary of nanomaterials used in the treatment of Candida auris infections. 
Table 6. Nanomaterials used in the treatment of Candida auris infections.

\begin{tabular}{|c|c|c|}
\hline Nanomaterial & Antifungal Effect & Reference \\
\hline Silver nanoparticles (AgNPs) & $\begin{array}{l}\text { Biofilm formation inhibition, planktonic } \\
\text { growth inhibition }\end{array}$ & {$[146,148]$} \\
\hline $\begin{array}{l}\text { Trimetallic nanoparticles } \\
\text { (Ag-Cu-Co NPs) }\end{array}$ & $\begin{array}{l}\text { Growth reduction, lower viability, cellular } \\
\text { arrest, mitochondria membrane damage }\end{array}$ & [149] \\
\hline $\begin{array}{l}\text { Bismuth nanoparticles } \\
\text { (BiNPs) }\end{array}$ & $\begin{array}{l}\text { Affect cellular morphology, biofilm } \\
\text { formation inhibition }\end{array}$ & [150] \\
\hline Nitric oxide (NO) & $\begin{array}{l}\text { Biofilm formation reduction, planktonic } \\
\text { growth inhibition }\end{array}$ & [151] \\
\hline
\end{tabular}

\section{Conclusions}

The increase in invasive fungal diseases derived from the limited availability of antifungals and the development of drug resistance has shown a lack of effectiveness of current therapies. Thus, the need to find new therapeutic strategies is urgent. The continuous development of nanotechnology has favored the search and development of new and more effective therapeutic alternatives to treat invasive fungal infections. Different types of nanoformulations developed are currently being evaluated and optimized, which present improvements in the efficacy and few or null adverse that the conventional antifungals. The use of nanotechnology has allowed the development of formulations based on nanomaterials, such as metallic nanoparticles, incorporation of coating materials, complexes synthesized by green chemistry, or coupled with polymers, which can improve not only the effectiveness of the treatment but also the quality of life of the patient by reducing side effects, especially during prolonged therapies. Figure 1 summarizes the current pharmacological treatments and the new antifungal strategies for aspergillosis, coccidioidomycosis, mucormycosis, and candidiasis caused by Candida auris.

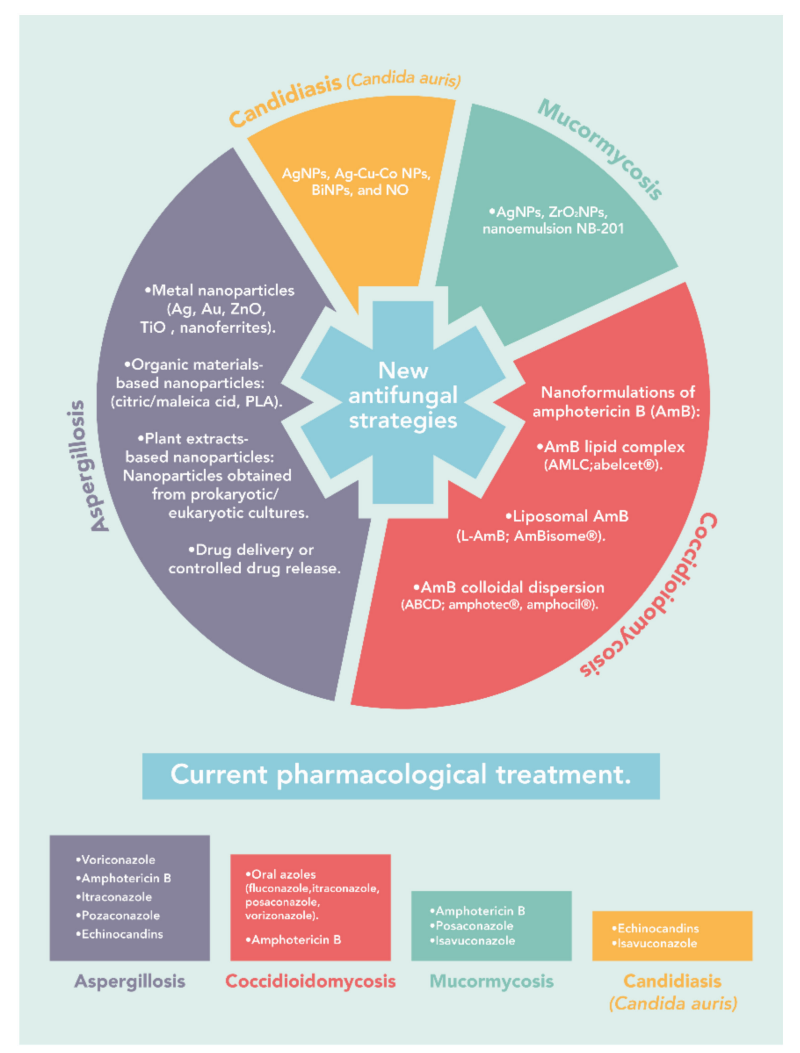

Figure 1. Current pharmacological treatments and the new antifungal strategies for aspergillosis, coccidioidomycosis, mucormycosis, and candidiasis caused by Candida auris. 
Various efforts are being made for the development of new drugs, as described in this review. However, the therapeutic alternatives to combat coccidioidomycosis and mucormycosis are limited or in the early development stages. The current COVID-19 pandemic has shown various factors associated with the increased prevalence of these fungal infections. Therefore, nanotechnology must continue to expand, and more research needs to be performed to develop new therapeutic alternatives that contribute to the progress of this field.

Author Contributions: Conceptualization, A.L.-B. and J.R.M.-R.; writing-original draft preparation, A.L.-B., J.A.G.-C., D.Y.G.-A., M.O.-C. and J.R.M.-R.; writing-review and editing, A.L.-B., J.A.G.-C., D.Y.G.-A., M.O.-C. and J.R.M.-R. All authors have read and agreed to the published version of the manuscript.

Funding: The authors want to thank to the Universidad Autonoma de Nuevo León and CONACyT for providing financial support through Paicyt 2019-2020, Paicyt 2020-2021 and Paicyt 2021-2022 Science Grants. CONACyT Grants for: Basic science grant 221332, Fronteras de la Ciencia grant 1502 Infraestructura Grant 279957 and Apoyo a la Ciencia de Frontera Grant 316869. J.A.G.-C for the support from a Beca Nacional de Posgrado from CONACyT and A.L.-B. for the support from a Beca de Posdoctorado Nacional.

Institutional Review Board Statement: Not applicable.

Informed Consent Statement: Not applicable.

Data Availability Statement: Not applicable.

Conflicts of Interest: The authors declare no conflict of interest.

\section{References}

1. Naranjo-Ortiz, M.A.; Gabaldón, T. Fungal evolution: Major ecological adaptations and evolutionary transitions. Biol. Rev. 2019, 94, 1443-1476. [CrossRef] [PubMed]

2. O'Brien, H.E.; Parrent, J.L.; Jackson, J.A.; Moncalvo, J.-M.; Vilgalys, R. Fungal Community Analysis by Large-Scale Sequencing of Environmental Samples. Appl. Environ. Microbiol. 2005, 71, 5544-5550. [CrossRef] [PubMed]

3. Köhler, J.R.; Hube, B.; Puccia, R.; Casadevall, A.; Perfect, J.R. Fungi that Infect Humans. Microbiol. Spectr. 2017, 5. [CrossRef] [PubMed]

4. Wall, G.; Lopez-Ribot, J.L. Current Antimycotics, New Prospects, and Future Approaches to Antifungal Therapy. Antibiotics 2020, 9, 445. [CrossRef] [PubMed]

5. Brown, G.D.; Denning, D.W.; Gow, N.A.R.; Levitz, S.M.; Netea, M.G.; White, T.C. Hidden Killers: Human Fungal Infections. Sci. Transl. Med. 2012, 4, 165rv13. [CrossRef] [PubMed]

6. Kim, J.-Y. Human fungal pathogens: Why should we learn? J. Microbiol. 2016, 54, 145-148. [CrossRef]

7. Prakash, H.; Chakrabarti, A. Global Epidemiology of Mucormycosis. J. Fungi 2019, 5, 26. [CrossRef] [PubMed]

8. Fisher, M.C.; Henk, D.A.; Briggs, C.J.; Brownstein, J.S.; Madoff, L.C.; McCraw, S.L.; Gurr, S.J. Emerging fungal threats to animal, plant and ecosystem health. Nature 2012, 484, 186-194. [CrossRef]

9. Santos, M.; Fonseca, A.; Mendonça, P.; Branco, R.; Serra, A.; Morais, P.; Coelho, J. Recent Developments in Antimicrobial Polymers: A Review. Materials 2016, 9, 599. [CrossRef] [PubMed]

10. Voltan, A.R.; Quindós, G.; Alarcón, K.P.M.; Fusco-Almeida, A.M.; Mendes-Giannini, M.J.S.; Chorilli, M. Fungal diseases: Could nanostructured drug delivery systems be a novel paradigm for therapy? Int. J. Nanomed. 2016, 11, 3715-3730. [CrossRef]

11. Perfect, J.R. The antifungal pipeline: A reality check. Nat. Rev. Drug Discov. 2017, 16, 603-616. [CrossRef]

12. Campoy, S.; Adrio, J.L. Antifungals. Biochem. Pharmacol. 2017, 133, 86-96. [CrossRef]

13. Chang, Y.-L.; Yu, S.-J.; Heitman, J.; Wellington, M.; Chen, Y.-L. New facets of antifungal therapy. Virulence 2017, 8, 222-236. [CrossRef]

14. Sardi, J.D.C.O.; Pitangui, N.D.S.; Rodríguez-Arellanes, G.; Taylor, M.L.; Fusco-Almeida, A.M.; Mendes-Giannini, M.J.S. Highlights in pathogenic fungal biofilms. Rev. Iberoam. Micol. 2014, 31, 22-29. [CrossRef]

15. Nagavarma, B.V.N.; Yadav, H.K.S.; Ayaz, A.; Vasudha, L.S.; Shivakumar, H.G. Different techniques for preparation of polymeric nanoparticles-A review. Asian J. Pharm. Clin. Res. 2012, 5, 16-23.

16. Escárcega-González, C.E.; Garza-Cervantes, J.A.; Vázquez-Rodríguez, A.; Morones-Ramírez, J.R. Bacterial Exopolysaccharides as Reducing and/or Stabilizing Agents during Synthesis of Metal Nanoparticles with Biomedical Applications. Int. J. Polym. Sci. 2018, 2018, 7045852. [CrossRef] 
17. Garza-Cervantes, J.A.; Escárcega-González, C.E.; Barriga Castro, E.D.; Mendiola-Garza, G.; Marichal-Cancino, B.A.; López-Vázquez, M.A.; Morones-Ramirez, J.R. Antimicrobial and antibiofilm activity of biopolymer-Ni, Zn nanoparticle biocomposites synthesized using R. mucilaginosa UANL-001L exopolysaccharide as a capping agent. Int. J. Nanomed. 2019, 14, 2557-2571. [CrossRef] [PubMed]

18. Vazquez-Rodriguez, A.; Vasto-Anzaldo, X.G.; Leon-Buitimea, A.; Zárate, X.; Morones-Ramirez, J.R. Antibacterial and antibiofilm activity of biosynthesized silver nanoparticles coated with exopolysaccharides obtained from Rhodotorula mucilaginosa. IEEE Trans. Nanobiosci. 2020, 19, 498-503. [CrossRef]

19. Pelgrift, R.Y.; Friedman, A.J. Nanotechnology as a therapeutic tool to combat microbial resistance. Adv. Drug Deliv. Rev. 2013, 65, 1803-1815. [CrossRef]

20. Bhatt, P.; Lalani, R.; Vhora, I.; Patil, S.; Amrutiya, J.; Misra, A.; Mashru, R. Liposomes encapsulating native and cyclodextrin enclosed paclitaxel: Enhanced loading efficiency and its pharmacokinetic evaluation. Int. J. Pharm. 2018, 536, 95-107. [CrossRef] [PubMed]

21. Sousa, F.; Ferreira, D.; Reis, S.; Costa, P. Current Insights on Antifungal Therapy: Novel Nanotechnology Approaches for Drug Delivery Systems and New Drugs from Natural Sources. Pharmaceuticals 2020, 13, 248. [CrossRef]

22. Morones-Ramirez, J.R.; Winkler, J.A.; Spina, C.S.; Collins, J.J. Silver Enhances Antibiotic Activity Against Gram-Negative Bacteria. Sci. Transl. Med. 2013, 5, 190ra81. [CrossRef]

23. Escárcega-González, C.E.; Garza-Cervantes, J.A.; Vazquez-Rodríguez, A.; Montelongo-Peralta, L.Z.; Treviño-Gonzalez, M.T.; Díaz Barriga Castro, E.; Saucedo-Salazar, E.M.; Chávez Morales, R.M.; Regalado-Soto, D.I.; Treviño-González, F.M.; et al. In vivo antimicrobial activity of silver nanoparticles produced via a green chemistry synthesis using Acacia rigidula as a reducing and capping agent. Int. J. Nanomed. 2018, 13, 2349-2363. [CrossRef]

24. Debourgogne, A.; Dorin, J.; Machouart, M. Emerging infections due to filamentous fungi in humans and animals: Only the tip of the iceberg? Environ. Microbiol. Rep. 2016, 8, 332-342. [CrossRef]

25. Abad, A.; Fernández-Molina, J.V.; Bikandi, J.; Ramírez, A.; Margareto, J.; Sendino, J.; Luis Hernando, F.; Pontón, J.; Garaizar, J.; Rementeria, A. What makes Aspergillus fumigatus a successful pathogen? Genes and molecules involved in invasive aspergillosis. Rev. Iberoam. Micol. 2010, 27, 155-182. [CrossRef]

26. Van der Torre, M.H.; Shen, H.; Rautemaa-Richardson, R.; Richardson, M.D.; Novak-Frazer, L. Molecular Epidemiology of Aspergillus fumigatus in Chronic Pulmonary Aspergillosis Patients. J. Fungi 2021, 7, 152. [CrossRef]

27. Thompson, G.; Brown, J.; Benedict, K.; Park, B. Coccidioidomycosis: Epidemiology. Clin. Epidemiol. 2013, 5, 185. [CrossRef] [PubMed]

28. Ashraf, N.; Kubat, R.C.; Poplin, V.; Adenis, A.A.; Denning, D.W.; Wright, L.; McCotter, O.; Schwartz, I.S.; Jackson, B.R.; Chiller, T.; et al. Re-drawing the Maps for Endemic Mycoses. Mycopathologia 2020, 185, 843-865. [CrossRef]

29. Jeong, W.; Keighley, C.; Wolfe, R.; Lee, W.L.; Slavin, M.A.; Kong, D.C.M.; Chen, S.C.-A. The epidemiology and clinical manifestations of mucormycosis: A systematic review and meta-analysis of case reports. Clin. Microbiol. Infect. 2019, 25, 26-34. [CrossRef] [PubMed]

30. Chow, N.A.; Muñoz, J.F.; Gade, L.; Berkow, E.L.; Li, X.; Welsh, R.M.; Forsberg, K.; Lockhart, S.R.; Adam, R.; Alanio, A.; et al. Tracing the Evolutionary History and Global Expansion of Candida auris Using Population Genomic Analyses. mBio 2020, 11, e03364-19. [CrossRef]

31. Du, H.; Bing, J.; Hu, T.; Ennis, C.L.; Nobile, C.J.; Huang, G. Candida auris: Epidemiology, biology, antifungal resistance, and virulence. PLoS Pathog. 2020, 16, e1008921. [CrossRef]

32. Schoch, C.L.; Ciufo, S.; Domrachev, M.; Hotton, C.L.; Kannan, S.; Khovanskaya, R.; Leipe, D.; Mcveigh, R.; O’Neill, K.; Robbertse, B.; et al. NCBI Taxonomy: A comprehensive update on curation, resources and tools. Database 2020, 2020 , baaa062. [CrossRef]

33. Auyeung, A.; Casillas-Santana, M.Á.; Martínez-Castañón, G.A.; Slavin, Y.N.; Zhao, W.; Asnis, J.; Häfeli, U.O.; Bach, H. Effective control of molds using a combination of nanoparticles. PLoS ONE 2017, 12, e0169940. [CrossRef]

34. Tekaia, F.; Latgé, J.P. Aspergillus fumigatus: Saprophyte or pathogen? Curr. Opin. Microbiol. 2005, 8, 385-392. [CrossRef]

35. Wéry, N. Bioaerosols from composting facilities-A review. Front. Cell. Infect. Microbiol. 2014, 4, 42.

36. Van De Veerdonk, F.L.; Gresnigt, M.S.; Romani, L.; Netea, M.G.; Latgé, J.P. Aspergillus fumigatus morphology and dynamic host interactions. Nat. Rev. Microbiol. 2017, 15, 661-674. [CrossRef] [PubMed]

37. Kosmidis, C.; Denning, D.W. The clinical spectrum of pulmonary aspergillosis. Thorax 2015, 70, 270-277. [CrossRef] [PubMed]

38. Kalkanci, A.; Ozdek, S. Ocular fungal infections. Curr. Eye Res. 2011, 36, 179-189. [CrossRef] [PubMed]

39. Walsh, T.J.; Anaissie, E.J.; Denning, D.W.; Herbrecht, R.; Kontoyiannis, D.P.; Marr, K.A.; Morrison, V.A.; Segal, B.H.; Steinbach, W.J.; Stevens, D.A.; et al. Treatment of aspergillosis: Clinical practice guidelines of the infectious diseases society of America. Clin. Infect. Dis. 2008, 46, 327-360. [CrossRef]

40. Kirkland, T.N.; Fierer, J. Coccidioides immitis and posadasii: A review of their biology, genomics, pathogenesis, and host immunity. Virulence 2018, 9, 1426-1435. [CrossRef] [PubMed]

41. Engelthaler, D.M.; Roe, C.C.; Hepp, C.M.; Teixeira, M.; Driebe, E.M.; Schupp, J.M.; Gade, L.; Waddell, V.; Komatsu, K.; Arathoon, E.; et al. Local population structure and patterns of Western Hemisphere dispersal for Coccidioides spp., the fungal cause of valley fever. mBio 2016, 7, 1-15. [CrossRef] [PubMed] 
42. Twarog, M.; Thompson, G. Coccidiodomicosis: Recent Update. Semin. Respir. Crit. Care Med. 2015, 36, 746-755. [CrossRef] [PubMed]

43. Diaz, J.H. Travel-related risk factors for coccidioidomycosis. J. Travel Med. 2018, 25, 1-8. [CrossRef] [PubMed]

44. Benedict, K.; Kobayashi, M.; Garg, S.; Chiller, T.; Jackson, B.R. Symptoms in Blastomycosis, Coccidioidomycosis, and Histoplasmosis versus Other Respiratory Illnesses in Commercially Insured Adult Outpatients-United States, 2016-2017. Clin. Infect. Dis. 2020, ciaa1554. [CrossRef] [PubMed]

45. Kollath, D.R.; Miller, K.J.; Barker, B.M. The mysterious desert dwellers: Coccidioides immitis and Coccidioides posadasii, causative fungal agents of coccidioidomycosis. Virulence 2019, 10, 222-233. [CrossRef]

46. Ibrahim, A.S.; Spellberg, B.; Walsh, T.J.; Kontoyiannis, D.P. Pathogenesis of Mucormycosis. Clin. Infect. Dis. 2012, 54, S16-S22. [CrossRef] [PubMed]

47. Uppuluri, P.; Alqarihi, A.; Ibrahim, A.S. Mucormycoses. In Encyclopedia of Mycology; Elsevier: Amsterdam, The Netherlands, 2021; pp. 600-612.

48. Hassan, M.I.A.; Voigt, K. Pathogenicity patterns of mucormycosis: Epidemiology, interaction with immune cells and virulence factors. Med. Mycol. 2019, 57, S245-S256. [CrossRef]

49. Mehta, S.; Pandey, A. Rhino-Orbital Mucormycosis Associated With COVID-19. Cureus 2020, 12, e10726. [CrossRef]

50. Sarkar, S.; Gokhale, T.; Choudhury, S.; Deb, A. COVID-19 and orbital mucormycosis. Indian J. Ophthalmol. 2021, 69, 1002. [CrossRef]

51. Singh, A.K.; Singh, R.; Joshi, S.R.; Misra, A. Mucormycosis in COVID-19: A systematic review of cases reported worldwide and in India. Diabetes Metab. Syndr. Clin. Res. Rev. 2021, 15, 102146. [CrossRef]

52. Revannavar, S.M.; Supriya, P.S.; Samaga, L.; Vineeth, V.K. COVID-19 triggering mucormycosis in a susceptible patient: A new phenomenon in the developing world? BMJ Case Rep. 2021, 14, e241663. [CrossRef] [PubMed]

53. Mba, I.E.; Nweze, E.I. The use of nanoparticles as alternative therapeutic agents against Candida infections: An up-to-date overview and future perspectives. World J. Microbiol. Biotechnol. 2020, 36, 163. [CrossRef] [PubMed]

54. Spivak, E.S.; Hanson, K.E. Candida auris: An Emerging Fungal Pathogen. J. Clin. Microbiol. 2018, 56, e01588-17. [CrossRef]

55. Satoh, K.; Makimura, K.; Hasumi, Y.; Nishiyama, Y.; Uchida, K.; Yamaguchi, H. Candida auris sp. nov., a novel ascomycetous yeast isolated from the external ear canal of an inpatient in a Japanese hospital. Microbiol. Immunol. 2009, 53, 41-44. [CrossRef] [PubMed]

56. Billamboz, M.; Fatima, Z.; Hameed, S.; Jawhara, S. Promising Drug Candidates and New Strategies for Fighting against the Emerging Superbug Candida auris. Microorganisms 2021, 9, 634. [CrossRef]

57. Lockhart, S.R.; Etienne, K.A.; Vallabhaneni, S.; Farooqi, J.; Chowdhary, A.; Govender, N.P.; Colombo, A.L.; Calvo, B.; Cuomo, C.A.; Desjardins, C.A.; et al. Simultaneous Emergence of Multidrug-Resistant Candida auris on 3 Continents Confirmed by WholeGenome Sequencing and Epidemiological Analyses. Clin. Infect. Dis. 2017, 64, 134-140. [CrossRef]

58. Jackson, B.R.; Chow, N.; Forsberg, K.; Litvintseva, A.P.; Lockhart, S.R.; Welsh, R.; Vallabhaneni, S.; Chiller, T. On the Origins of a Species: What Might Explain the Rise of Candida auris? J. Fungi 2019, 5, 58. [CrossRef]

59. Kean, R.; Sherry, L.; Townsend, E.; McKloud, E.; Short, B.; Akinbobola, A.; Mackay, W.G.; Williams, C.; Jones, B.L.; Ramage, G. Surface disinfection challenges for Candida auris: An in-vitro study. J. Hosp. Infect. 2018, 98, 433-436. [CrossRef]

60. Aigner, M.; Lass-Flörl, C. Treatment of drug-resistant Aspergillus infection. Expert Opin. Pharmacother. 2015, 16, 2267-2270. [CrossRef]

61. Pascual, A.; Csajka, C.; Buclin, T.; Bolay, S.; Bille, J.; Calandra, T.; Marchetti, O. Challenging recommended oral and intravenous voriconazole doses for improved efficacy and safety: Population pharmacokinetics-based analysis of adult patients with invasive fungal infections. Clin. Infect. Dis. 2012, 55, 381-390. [CrossRef]

62. Ampel, N.M. Tratamento da coccidioidomicose. Rev. Inst. Med. Trop. Sao Paulo 2015, 57, 51-56. [CrossRef] [PubMed]

63. Galgiani, J.N.; Ampel, N.M.; Blair, J.E.; Catanzaro, A.; Geertsma, F.; Hoover, S.E.; Johnson, R.H.; Kusne, S.; Lisse, J.; MacDonald, J.D.; et al. 2016 Infectious Diseases Society of America (IDSA) Clinical Practice Guideline for the Treatment of Coccidioidomycosis. Clin. Infect. Dis. 2016, 63, e112-e146. [CrossRef]

64. Thompson, G.R.; Lewis, J.S.; Nix, D.E.; Patterson, T.F. Current Concepts and Future Directions in the Pharmacology and Treatment of Coccidioidomycosis. Med. Mycol. 2019, 57, S76-S84. [CrossRef]

65. Wiederhold, N.P. Antifungal resistance: Current trends and future strategies to combat. Infect. Drug Resist. 2017, 10, 249-259. [CrossRef] [PubMed]

66. Sidhu, R.; Lash, D.B.; Heidari, A.; Natarajan, P.; Johnson, R.H. Evaluation of Amphotericin B Lipid Formulations for Treatment of Severe Coccidioidomycosis. Antimicrob. Agents Chemother. 2018, 62. [CrossRef]

67. Antoniadou, A.; Dupont, B. Lipid formulations of amphotericin B: Where are we today? J. Mycol. Med. 2005, 15, 230-238. [CrossRef]

68. Skiada, A.; Lass-Floerl, C.; Klimko, N.; Ibrahim, A.; Roilides, E.; Petrikkos, G. Challenges in the diagnosis and treatment of mucormycosis. Med. Mycol. 2018, 56, S93-S101. [CrossRef]

69. Sipsas, N.V.; Gamaletsou, M.N.; Anastasopoulou, A.; Kontoyiannis, D.P. Therapy of Mucormycosis. J. Fungi 2018, 4, 90. [CrossRef]

70. Jenks, J.D.; Salzer, H.J.F.; Prattes, J.; Krause, R.; Buchheidt, D.; Hoenigl, M. Spotlight on isavuconazole in the treatment of invasive aspergillosis and mucormycosis: Design, development, and place in therapy. Drug Des. Dev. Ther. 2018, 12, 1033-1044. [CrossRef] 
71. Chakrabarti, A.; Sood, P.; Rudramurthy, S.M.; Chen, S.; Kaur, H.; Capoor, M.; Chhina, D.; Rao, R.; Eshwara, V.K.; Xess, I.; et al. Incidence, characteristics and outcome of ICU-acquired candidemia in India. Intensive Care Med. 2014, 41, 285-295. [CrossRef]

72. Sardi, J.d.C.O.; Silva, D.R.; Mendes-Giannini, M.J.S.; Rosalen, P.L. Candida auris: Epidemiology, risk factors, virulence, resistance, and therapeutic options. Microb. Pathog. 2018, 125, 116-121. [CrossRef]

73. Larkin, E.; Hager, C.; Chandra, J.; Mukherjee, P.K.; Retuerto, M.; Salem, I.; Long, L.; Isham, N.; Kovanda, L.; Borroto-Esoda, K.; et al. The Emerging Pathogen Candida auris: Growth Phenotype, Virulence Factors, Activity of Antifungals, and Effect of SCY-078, a Novel Glucan Synthesis Inhibitor, on Growth Morphology and Biofilm Formation. Antimicrob. Agents Chemother. 2017, 61, e02396-16. [CrossRef] [PubMed]

74. Dilshad, E.; Bibi, M.; Sheikh, N.A.; Tamrin, K.F.; Mansoor, Q.; Maqbool, Q.; Nawaz, M. Synthesis of functional silver nanoparticles and microparticles with modifiers and evaluation of their antimicrobial, anticancer, and antioxidant activity. J. Funct. Biomater. 2020, 11, 76. [CrossRef]

75. Jung, S.H.; Lim, D.H.; Jung, S.H.; Lee, J.E.; Jeong, K.-S.; Seong, H.; Shin, B.C. Amphotericin B-entrapping lipid nanoparticles and their in vitro and in vivo characteristics. Eur. J. Pharm. Sci. 2009, 37, 313-320. [CrossRef]

76. Hasan, S. A Review on Nanoparticles: Their Synthesis and Types. Res. J. Recent Sci. Uttar Pradesh 2014, 4, 1-3.

77. Ealia, S.A.M.; Saravanakumar, M.P. A review on the classification, characterisation, synthesis of nanoparticles and their application. IOP Conf. Ser. Mater. Sci. Eng. 2017, 263, 032019. [CrossRef]

78. Cho, E.J.; Holback, H.; Liu, K.C.; Abouelmagd, S.A.; Park, J.; Yeo, Y. Nanoparticle Characterization: State of the Art, Challenges, and Emerging Technologies. Mol. Pharm. 2013, 10, 2093-2110. [CrossRef]

79. Lee, J.E.; Lee, N.; Kim, T.; Kim, J.; Hyeon, T. Multifunctional mesoporous silica nanocomposite nanoparticles for theranostic applications. Acc. Chem. Res. 2011, 44, 893-902. [CrossRef]

80. Barrak, H.; Saied, T.; Chevallier, P.; Laroche, G.; M'nif, A.; Hamzaoui, A.H. Synthesis, characterization, and functionalization of $\mathrm{ZnO}$ nanoparticles by N-(trimethoxysilylpropyl) ethylenediamine triacetic acid (TMSEDTA): Investigation of the interactions between Phloroglucinol and ZnO@TMSEDTA. Arab. J. Chem. 2019, 12, 4340-4347. [CrossRef]

81. Khan, I.; Saeed, K.; Khan, I. Nanoparticles: Properties, applications and toxicities. Arab. J. Chem. 2019, 12, 908-931. [CrossRef]

82. Yin, L.; Zhong, Z. Nanoparticles. In Biomaterials Science; Elsevier: Amsterdam, The Netherlands, 2020; pp. 453-483.

83. Mitchell, M.J.; Billingsley, M.M.; Haley, R.M.; Wechsler, M.E.; Peppas, N.A.; Langer, R. Engineering precision nanoparticles for drug delivery. Nat. Rev. Drug Discov. 2021, 20, 101-124. [CrossRef]

84. Jeevanandam, J.; Barhoum, A.; Chan, Y.S.; Dufresne, A.; Danquah, M.K. Review on nanoparticles and nanostructured materials: History, sources, toxicity and regulations. Beilstein J. Nanotechnol. 2018, 9, 1050-1074. [CrossRef] [PubMed]

85. Tiwari, D.K.; Behari, J.; Sen, P. Application of Nanoparticles in Waste Water Treatment. Mater. Sci. 2008, 3, 417-433.

86. Garza-Cervantes, J.A.; Meza-Bustillos, J.F.; Resendiz-Hernandez, H.; Suarez-Cantú, I.A.; Ortega-Rivera, O.A.; Salinas, E.; Escarcega-Gonzalez, C.E.; Morones-Ramirez, J.R. Re-sensitizing ampicillin and kanamycin-resistant E. coli and S. aureus using synergistic metal micronutrients-antibiotic combinations. Front. Bioeng. Biotechnol. 2020, 8, 612. [CrossRef] [PubMed]

87. Vivek, M.; Kumar, P.S.; Steffi, S.; Sudha, S. Biogenic silver nanoparticles by gelidiella acerosa extract and their antifungal effects. Avicenna J. Med. Biotechnol. 2011, 3, 143-148.

88. Miri, A.; Mahdinejad, N.; Ebrahimy, O.; Khatami, M.; Sarani, M. Zinc oxide nanoparticles: Biosynthesis, characterization, antifungal and cytotoxic activity. Mater. Sci. Eng. C 2019, 104, 109981. [CrossRef]

89. Quirós, J.; Gonzalo, S.; Jalvo, B.; Boltes, K.; Perdigón-Melón, J.A.; Rosal, R. Electrospun cellulose acetate composites containing supported metal nanoparticles for antifungal membranes. Sci. Total Environ. 2016, 563-564, 912-920. [CrossRef]

90. Montelongo-Peralta, L.Z.; León-Buitimea, A.; Palma-Nicolás, J.P.; Gonzalez-Christen, J.; Morones-Ramírez, J.R. Antibacterial Activity of combinatorial treatments composed of transition-metal/antibiotics against Mycobacterium tuberculosis. Sci. Rep. 2019, 9, 5471. [CrossRef]

91. Padilla-Cruz, A.L.; Garza-Cervantes, J.A.; Vasto-Anzaldo, X.G.; García-Rivas, G.; León-Buitimea, A.; Morones-Ramírez, J.R. Synthesis and design of Ag-Fe bimetallic nanoparticles as antimicrobial synergistic combination therapies against clinically relevant pathogens. Sci. Rep. 2021, 11, 5351. [CrossRef]

92. Ogar, A.; Tylko, G.; Turnau, K. Antifungal properties of silver nanoparticles against indoor mould growth. Sci. Total Environ. 2015, 521-522, 305-314. [CrossRef]

93. Xu, Y.; Gao, C.; Li, X.; He, Y.; Zhou, L.; Pang, G.; Sun, S. In vitro antifungal activity of silver nanoparticles against ocular pathogenic filamentous fungi. J. Ocul. Pharmacol. Ther. 2013, 29, 270-274. [CrossRef] [PubMed]

94. Sayed, M.A.; Abdelsalam, H.K.; El-Bassuony, A.A.H. Antimicrobial activity of Novel spinel nanoferrites against pathogenic fungi and bacteria. World J. Microbiol. Biotechnol. 2020, 36, 25. [CrossRef] [PubMed]

95. Pandey, S.; De Klerk, C.; Kim, J.; Kang, M.; Fosso-Kankeu, E. Eco friendly approach for synthesis, characterization and biological activities of milk protein stabilized silver nanoparticles. Polymers 2020, 12, 1418. [CrossRef] [PubMed]

96. Selvaraj, V.; Alagar, M. Analytical detection and biological assay of antileukemic drug 5-fluorouracil using gold nanoparticles as probe. Int. J. Pharm. 2007, 337, 275-281. [CrossRef]

97. Fonseca, C.; Ochoa, A.; Ulloa, M.T.; Alvarez, E.; Canales, D.; Zapata, P.A. Poly(lactic acid)/TiO2 nanocomposites as alternative biocidal and antifungal materials. Mater. Sci. Eng. C 2015, 57, 314-320. [CrossRef] 
98. Leudjo Taka, A.; Doyle, B.P.; Carleschi, E.; Youmbi Fonkui, T.; Erasmus, R.; Fosso-Kankeu, E.; Pillay, K.; Mbianda, X.Y. Spectroscopic characterization and antimicrobial activity of nanoparticle doped cyclodextrin polyurethane bionanosponge. Mater. Sci. Eng. C 2020, 115, 111092. [CrossRef]

99. Mane, P.C.; Chaudhari, R.D.; Shinde, M.D.; Kadam, D.D.; Song, C.K.; Amalnerkar, D.P.; Lee, H. Designing Ecofriendly Bionanocomposite Assembly with Improved Antimicrobial and Potent on-site Zika Virus Vector Larvicidal Activities with its Mode of Action. Sci. Rep. 2017, 7, 15531. [CrossRef]

100. Sabira, S.F.; Kasabe, A.M.; Mane, P.C.; Chaudhari, R.D.; Adhyapak, P.V. Selective antifungal and antibacterial activities of Ag-Cu and $\mathrm{Cu}$-Ag core-shell nanostructures synthesized in-situ PVA. Nanotechnology 2020, 31, 485705. [CrossRef]

101. Salama, H.E.; Saad, G.R.; Sabaa, M.W. Synthesis, characterization, and biological activity of cross-linked chitosan biguanidine loaded with silver nanoparticles. J. Biomater. Sci. Polym. Ed. 2016, 27, 1880-1898. [CrossRef]

102. Garza-Cervantes, J.A.; Mendiola-Garza, G.; de Melo, E.M.; Dugmore, T.I.J.; Matharu, A.S.; Morones-Ramirez, J.R. Antimicrobial activity of a silver-microfibrillated cellulose biocomposite against susceptible and resistant bacteria. Sci. Rep. 2020, $10,7281$. [CrossRef]

103. Jaffri, S.B.; Ahmad, K.S. Neoteric environmental detoxification of organic pollutants and pathogenic microbes via green synthesized ZnO nanoparticles. Environ. Technol. 2019, 40, 3745-3761. [CrossRef] [PubMed]

104. Khan, Z.U.H.; Sadiq, H.M.; Shah, N.S.; Khan, A.U.; Muhammad, N.; Hassan, S.U.; Tahir, K.; Safi, S.Z.; Khan, F.U.; Imran, M.; et al. Greener synthesis of zinc oxide nanoparticles using Trianthema portulacastrum extract and evaluation of its photocatalytic and biological applications. J. Photochem. Photobiol. B Biol. 2019, 192, 147-157. [CrossRef] [PubMed]

105. Lateef, A.; Akande, M.A.; Ojo, S.A.; Folarin, B.I.; Gueguim-Kana, E.B.; Beukes, L.S. Paper wasp nest-mediated biosynthesis of silver nanoparticles for antimicrobial, catalytic, anticoagulant, and thrombolytic applications. 3 Biotech 2016, 6, 140. [CrossRef] [PubMed]

106. Lateef, A.; Folarin, B.I.; Oladejo, S.M.; Akinola, P.O.; Beukes, L.S.; Gueguim-Kana, E.B. Characterization, antimicrobial, antioxidant, and anticoagulant activities of silver nanoparticles synthesized from Petiveria alliacea L. leaf extract. Prep. Biochem. Biotechnol. 2018, 48, 646-652. [CrossRef]

107. El Sayed, M.T.; El-Sayed, A.S.A. Biocidal activity of metal nanoparticles synthesized by fusarium solani against multidrug-resistant bacteria and mycotoxigenic fungi. J. Microbiol. Biotechnol. 2020, 30, 226-236. [CrossRef]

108. Lipovsky, A.; Nitzan, Y.; Gedanken, A.; Lubart, R. Antifungal activity of ZnO nanoparticles-the role of ROS mediated cell injury. Nanotechnology 2011, 22, 105101. [CrossRef]

109. Hashem, A.H.; Khalil, A.M.A.; Reyad, A.M.; Salem, S.S. Biomedical Applications of Mycosynthesized Selenium Nanoparticles Using Penicillium expansum ATTC 36200. Biol. Trace Elem. Res. 2021, 199, 3998-4008. [CrossRef]

110. Khan, T.; Yasmin, A.; Townley, H.E. An evaluation of the activity of biologically synthesized silver nanoparticles against bacteria, fungi and mammalian cell lines. Colloids Surf. B Biointerfaces 2020, 194, 111156. [CrossRef]

111. Ojo, S.A.; Lateef, A.; Azeez, M.A.; Oladejo, S.M.; Akinwale, A.S.; Asafa, T.B.; Yekeen, T.A.; Akinboro, A.; Oladipo, I.C.; Gueguim-Kana, E.B.; et al. Biomedical and Catalytic Applications of Gold and Silver-Gold Alloy Nanoparticles Biosynthesized Using Cell-Free Extract of Bacillus Safensis LAU 13: Antifungal, Dye Degradation, Anti-Coagulant and Thrombolytic Activities. IEEE Trans. Nanobiosci. 2016, 15, 433-442. [CrossRef]

112. Shakibaie, M.; Mohazab, N.S.; Ayatollahi Mousavi, S.A. Antifungal activity of selenium nanoparticles synthesized by bacillus species Msh-1 against Aspergillus fumigatus and Candida albicans. Jundishapur J. Microbiol. 2015, 8, 26381. [CrossRef] [PubMed]

113. Thenmozhi, M.; Kannabiran, K.; Kumar, R.; Gopiesh Khanna, V. Antifungal activity of Streptomyces sp. VITSTK7 and its synthesized Ag2O/Ag nanoparticles against medically important Aspergillus pathogens. J. Mycol. Med. 2013, $23,97-103$. [CrossRef]

114. Roy, I.; Thapa, M.; Goswami, A. Nanohexaconazole: Synthesis, characterisation and efficacy of a novel fungicidal nanodispersion. IET Nanobiotechnol. 2018, 12, 864-868. [CrossRef] [PubMed]

115. Bhatta, R.S.; Chandasana, H.; Chhonker, Y.S.; Rathi, C.; Kumar, D.; Mitra, K.; Shukla, P.K. Mucoadhesive nanoparticles for prolonged ocular delivery of natamycin: In vitro and pharmacokinetics studies. Int. J. Pharm. 2012, 432, 105-112. [CrossRef] [PubMed]

116. Chhonker, Y.S.; Prasad, Y.D.; Chandasana, H.; Vishvkarma, A.; Mitra, K.; Shukla, P.K.; Bhatta, R.S. Amphotericin-B entrapped lecithin/chitosan nanoparticles for prolonged ocular application. Int. J. Biol. Macromol. 2015, 72, 1451-1458. [CrossRef]

117. Malhotra, S.; Singh, S.; Rana, N.; Tomar, S.; Bhatnagar, P.; Gupta, M.; Singh, S.K.; Singh, B.K.; Chhillar, A.K.; Prasad, A.K.; et al Chemoenzymatic synthesis, nanotization, and anti-Aspergillus activity of optically enriched fluconazole analogues. Antimicrob. Agents Chemother. 2017, 61, e00273-17. [CrossRef]

118. Fukui, H.; Koike, T.; Nakagawa, T.; Saheki, A.; Sonoke, S.; Tomii, Y.; Seki, J. Comparison of LNS-AmB, a novel low-dose formulation of amphotericin B with lipid nano-sphere (LNS®), with commercial lipid-based formulations. Int. J. Pharm. 2003, 267, 101-112. [CrossRef]

119. Van De Ven, H.; Paulussen, C.; Feijens, P.B.; Matheeussen, A.; Rombaut, P.; Kayaert, P.; Van Den Mooter, G.; Weyenberg, W.; Cos, P.; Maes, L.; et al. PLGA nanoparticles and nanosuspensions with amphotericin B: Potent in vitro and in vivo alternatives to Fungizone and AmBisome. J. Control. Release 2012, 161, 795-803. [CrossRef] [PubMed]

120. Shirkhani, K.; Teo, I.; Armstrong-James, D.; Shaunak, S. Nebulised amphotericin B-polymethacrylic acid nanoparticle prophylaxis prevents invasive aspergillosis. Nanomed. Nanotechnol. Biol. Med. 2015, 11, 1217-1226. [CrossRef] [PubMed] 
121. Khames, A.; Khaleel, M.A.; El-Badawy, M.F.; El-Nezhawy, A.O.H. Natamycin solid lipid nanoparticles - sustained ocular delivery system of higher corneal penetration against deep fungal keratitis: Preparation and optimization. Int. J. Nanomed. 2019, 14, 2515-2531. [CrossRef]

122. Lakhani, P.; Patil, A.; Wu, K.W.; Sweeney, C.; Tripathi, S.; Avula, B.; Taskar, P.; Khan, S.; Majumdar, S. Optimization, stabilization, and characterization of amphotericin B loaded nanostructured lipid carriers for ocular drug delivery. Int. J. Pharm. 2019, 572, 118771. [CrossRef]

123. Chellat, F.; Merhi, Y.; Moreau, A.; Yahia, L. Therapeutic potential of nanoparticulate systems for macrophage targeting. Biomaterials 2005, 26, 7260-7275. [CrossRef] [PubMed]

124. Hamill, R.J. Amphotericin B formulations: A comparative review of efficacy and toxicity. Drugs 2013, 73, 919-934. [CrossRef] [PubMed]

125. Garcia, M.P.; Santos, M.d.F.M.A.; Saldanha, C.A.; Iocca, D.C.; Azevedo, R.B. Amphotericin B: An antifungal drug in nanoformulations for the treatment of paracoccidioidomycosis. Rev. Univ. Ind. Santander. Salud 2013, 45, 45-53.

126. Faustino, C.; Pinheiro, L. Lipid Systems for the Delivery of Amphotericin B in Antifungal Therapy. Pharmaceutics 2020, 12, 29. [CrossRef]

127. Furebring, M.; Öberg, G.; Sjölin, J. Side-effects of Amphotericin B lipid complex (Abelcet) in the Scandinavian population. Bone Marrow Transplant. 2000, 25, 341-342. [CrossRef] [PubMed]

128. Stewart, E.R.; Eldridge, M.L.; McHardy, I.; Cohen, S.H.; Thompson, G.R. Liposomal Amphotericin B as Monotherapy in Relapsed Coccidioidal Meningitis. Mycopathologia 2018, 183, 619-622. [CrossRef]

129. Antony, S.; Dominguez, D.C.; Sotelo, E. Use of liposomal amphotericin B in the treatment of disseminated coccidioidomycosis. J. Natl. Med. Assoc. 2003, 95, 982-985.

130. Gómez Rivera, N.; Dorame Castillo, R.; Contreras Soto, J.; Talamante, S. Tratamiento de coccidioidomicosis meníngea con anfotericina liposomal: Presentación de un caso. Boletín Médico Hosp. Infant. México (Ed. Española) 2010, 67, 142-146.

131. Nakhla, S.G. Complications and Management of a Rare Case of Disseminated Coccidioidomycosis to the Vertebral Spine. Case Rep. Infect. Dis. 2018, 2018, 8954016. [CrossRef]

132. Clemons, K.V.; Capilla, J.; Sobel, R.A.; Martinez, M.; Tong, A.-J.; Stevens, D.A. Comparative Efficacies of Lipid-Complexed Amphotericin B and Liposomal Amphotericin B against Coccidioidal Meningitis in Rabbits. Antimicrob. Agents Chemother. 2009, 53, 1858-1862. [CrossRef]

133. González, G.M.; Tijerina, R.; Najvar, L.K.; Bocanegra, R.; Rinaldi, M.G.; Graybill, J.R. Efficacies of Amphotericin B (AMB) Lipid Complex, AMB Colloidal Dispersion, Liposomal AMB, and Conventional AMB in Treatment of Murine Coccidioidomycosis. Antimicrob. Agents Chemother. 2004, 48, 2140-2143. [CrossRef]

134. Roden, M.M.; Zaoutis, T.E.; Buchanan, W.L.; Knudsen, T.A.; Sarkisova, T.A.; Schaufele, R.L.; Sein, M.; Sein, T.; Chiou, C.C.; Chu, J.H.; et al. Epidemiology and Outcome of Zygomycosis: A Review of 929 Reported Cases. Clin. Infect. Dis. 2005, 41, 634-653. [CrossRef]

135. Schwarz, P.; Cornely, O.A.; Dannaoui, E. Antifungal combinations in Mucorales: A microbiological perspective. Mycoses 2019, 62, 746-760. [CrossRef]

136. Dannaoui, E. Antifungal resistance in mucorales. Int. J. Antimicrob. Agents 2017, 50, 617-621. [CrossRef] [PubMed]

137. Cornely, O.A.; Arikan-Akdagli, S.; Dannaoui, E.; Groll, A.H.; Lagrou, K.; Chakrabarti, A.; Lanternier, F.; Pagano, L.; Skiada, A.; Akova, M.; et al. ESCMID and ECMM joint clinical guidelines for the diagnosis and management of mucormycosis 2013. Clin. Microbiol. Infect. 2014, 20, 5-26. [CrossRef] [PubMed]

138. George, C.; Kuriakose, S.; George, S.; Mathew, T. Antifungal activity of silver nanoparticle-encapsulated $\beta$-cyclodextrin against human opportunistic pathogens. Supramol. Chem. 2011, 23, 593-597. [CrossRef]

139. Kumar, A.; Vemula, P.K.; Ajayan, P.M.; John, G. Silver-nanoparticle-embedded antimicrobial paints based on vegetable oil. Nat. Mater. 2008, 7, 236-241. [CrossRef]

140. Mohamed, D.Y. Detection the antifungal effect of zirconium oxide nanoparticles on mold which isolated from domestic's bathroom. Al-Mustansiriyah J. Sci. 2018, 29, 15-22. [CrossRef]

141. Cao, Z.; Spilker, T.; Fan, Y.; Kalikin, L.M.; Ciotti, S.; LiPuma, J.J.; Makidon, P.E.; Wilkinson, J.E.; Baker, J.R.; Wang, S.H. Nanoemulsion is an effective antimicrobial for methicillin-resistant Staphylococcus aureus in infected wounds. Nanomedicine 2017, 12, 1177-1185. [CrossRef]

142. Brunet, K.; Rammaert, B. Mucormycosis treatment: Recommendations, latest advances, and perspectives. J. Mycol. Med. 2020, 30, 101007. [CrossRef]

143. Basketter, D.A.; Marriott, M.; Gilmour, N.J.; White, I.R. Strong irritants masquerading as skin allergens: The case of benzalkonium chloride. Contact Dermat. 2004, 50, 213-217. [CrossRef] [PubMed]

144. Garcia, A.; Fan, Y.Y.; Vellanki, S.; Huh, E.Y.; Vanegas, D.; Wang, S.H.; Lee, S.C. Nanoemulsion as an Effective Treatment against Human-Pathogenic Fungi. mSphere 2019, 4, e00729-19. [CrossRef] [PubMed]

145. Rivero, P.J.; Urrutia, A.; Goicoechea, J.; Arregui, F.J. Nanomaterials for Functional Textiles and Fibers. Nanoscale Res. Lett. 2015, 10, 501. [CrossRef] [PubMed]

146. Lara, H.H.; Ixtepan-Turrent, L.; Jose Yacaman, M.; Lopez-Ribot, J. Inhibition of Candida auris Biofilm Formation on Medical and Environmental Surfaces by Silver Nanoparticles. ACS Appl. Mater. Interfaces 2020, 12, 21183-21191. [CrossRef] 
147. Lara, H.H.; Romero-Urbina, D.G.; Pierce, C.; Lopez-Ribot, J.L.; Arellano-Jiménez, M.J.; Jose-Yacaman, M. Effect of silver nanoparticles on Candida albicans biofilms: An ultrastructural study. J. Nanobiotechnol. 2015, 13, 91. [CrossRef]

148. Vazquez-Munoz, R.; Lopez, F.D.; Lopez-Ribot, J.L. Silver Nanoantibiotics Display Strong Antifungal Activity Against the Emergent Multidrug-Resistant Yeast Candida auris Under Both Planktonic and Biofilm Growing Conditions. Front. Microbiol. 2020, 11, 1673. [CrossRef]

149. Kamli, M.R.; Srivastava, V.; Hajrah, N.H.; Sabir, J.S.M.; Hakeem, K.R.; Ahmad, A.; Malik, M.A. Facile Bio-Fabrication of Ag-Cu-Co Trimetallic Nanoparticles and Its Fungicidal Activity against Candida auris. J. Fungi 2021, 7, 62. [CrossRef]

150. Vazquez-Munoz, R.; Lopez, F.D.; Lopez-Ribot, J.L. Bismuth Nanoantibiotics Display Anticandidal Activity and Disrupt the Biofilm and Cell Morphology of the Emergent Pathogenic Yeast Candida auris. Antibiotics 2020, 9, 461. [CrossRef]

151. Cleare, L.G.; Li, K.L.; Abuzeid, W.M.; Nacharaju, P.; Friedman, J.M.; Nosanchuk, J.D. NO Candida auris: Nitric Oxide in Nanotherapeutics to Combat Emerging Fungal Pathogen Candida auris. J. Fungi 2020, 6, 85. [CrossRef] [PubMed] 